\title{
Mantle transect of the Karelian Craton from margin to core based on P-T data from garnet and clinopyroxene xenocrysts in kimberlites
}

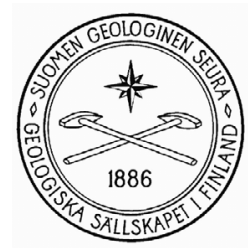

\author{
Marja Lehtonen* and Hugh O’Brien \\ Geological Survey of Finland, P.O. Box 96, FI-02151, Espoo, Finland
}

\begin{abstract}
Peridotitic garnet and clinopyroxene xenocrysts from the 1.2 Ga Lentiira-Kuhmo and the 760 Ma Kuusamo kimberlite fields, emplaced within the Central Karelian Craton, have been studied using major and trace element geochemistry to obtain information on the stratigraphy, compositional variability, and evolutionary history of the underlying lithospheric mantle. An earlier study on the 600 Ma Kaavi-Kuopio kimberlite field showed that near the SW margin of the craton the 230-km-thick subcontinental lithospheric mantle (SCLM) exhibits a well-developed 3-layer structure indicative of episodic construction. New Ni in garnet thermometry on samples farther into the craton, from Kuhmo, Lentiira, and southern and northern Kuusamo, gives temperature ranges of 800-1400, 700-1450, 700-1450 and $600-1300{ }^{\circ} \mathrm{C}$, respectively, and when extrapolated to the geotherm determined for the Kaavi-Kuopio area, indicates sampling intervals of c. 100-240, 80-250, 80-250 and 65-2 10 $\mathrm{km}$, respectively. The results demonstrate that the SCLM of the Karelian Craton reaches its greatest thickness in the Lentiira-Kuhmo and southern Kuusamo area and thins towards the North and South. The mantle stratigraphy of the craton core, compared to the craton edge, shows less compositional variation, with only two distinguishable horizons corresponding generally to the two deepest layers at Kaavi-Kuopio. Additionally, based on the $\mathrm{Mg \#}$ of pyropes, the level of depletion of peridotites comprising the mantle lithosphere in the central craton is significantly higher than at the craton edge represented by Kaavi-Kuopio. Coupled with the rarity of mantle-derived chrome diopside, the implication is that this portion of the mantle either underwent high levels of partial melting to produce very refractory residua or experienced less melt-modification than average SCLM subsequent to formation. The craton core provides a wide diamond window up to $110 \mathrm{~km}$ thick compared to c. $40 \mathrm{~km}$ at the craton edge.
\end{abstract}

Keywords: kimberlite, lithosphere, mantle, xenocrysts, pyrope, Finland

*Corresponding author email: marja.lehtonen@gtk.fi

\section{Introduction}

The Archean eastern and northern parts of the Fennoscandian Shield comprise the Karelian-Kola-Kuloimegacraton, which hosts numerous kimberlitic rocks representing various ages and mineralogical types
(Fig. 1). From oldest to youngest the known kimberlite provinces in the region are: 1 . Kemozero, located on the northern shore of Lake Onega and dated at $1760 \mathrm{Ma}$ (Lobkova et al., 2006). 2. Lentiira-Kuh- 


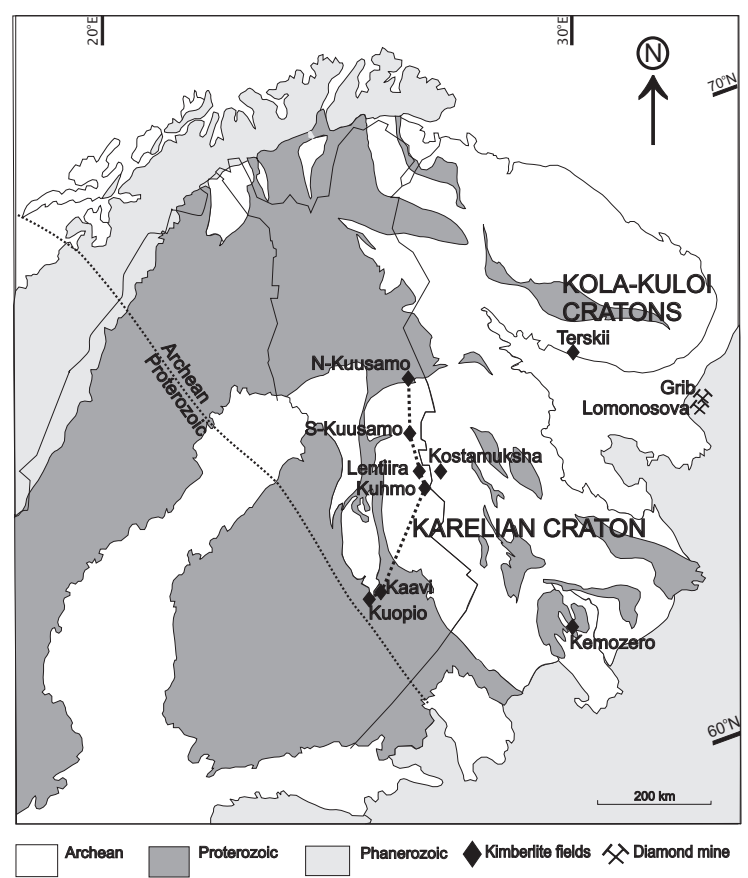

Figure I. Generalized geological map of Fennoscandia. The Archean/Proterozoic boundary marks the subsurface extent of the Archean craton as determined by $\mathrm{Nd}$ isotopes. The black diamonds represent diamond-bearing kimberlites and lamproites, the diamond mines in the Arkhangelsk peninsula are also indicated. The lithospheric mantle cross section across the Karelian Craton presented in this study is indicated by a dashed line.

mo-Kostamuksha, covering both sides of the Finnish-Russian border, contains 1200 Ma dykes with characteristics of both olivine lamproites and Group II kimberlites (O'Brien et al., 2007; Antonov \& Ulianov, 2008). 3. Kaavi-Kuopio, where the bulk of the Finnish Group I kimberlites were emplaced about $600 \mathrm{Ma}$ ago (O’Brien \& Tyni, 1999; O’Brien et al., 2005). 4. Kuusamo, where both Group I and Group II kimberlites have recently been discovered. Two of the Group I kimberlites have been dated and give the same $760 \mathrm{Ma}$ age within error. For this paper the Kuusamo kimberlites have been divided into northern $(\mathrm{N})$ and southern (S) Kuusamo fields. 5. Arkhangelsk and Terskii, which lie farther to the north and east, contain kimberlites of 360 to $380 \mathrm{Ma}$ in age (Mahotkin et al., 2000). These kimberlites represent members of the Devonian Kola Alkaline Province. Arkhangelsk kimberlites are divided geographically and minera- logically into Eastern mica-poor (Group I) and Western micaceous (Group II) subtypes (e.g. Beard et al., 2000). The Western group hosts Europe's first diamond mine, Lomonosova, which covers six individual kimberlite pipes. In the near future mining activity will also start in the Eastern Group when production at the Grip pipe commences.

\section{I.I Summary of results from Kaavi-Kuopio}

Previous studies of Kaavi-Kuopio kimberlite xenoliths and xenocrysts have demonstrated that the subcontinental lithospheric mantle (SCLM) sampled by these magmas at the Archean-Paleoproterozoic boundary is distinctly stratified. The mantle xenolith suite demonstrates that a shallow zone $\left(<900{ }^{\circ} \mathrm{C}\right)$ of garnet-spinel harzburgite is underlain by a zone of more fertile garnet peridotites (180-240 km, Peltonen et al., 1999). Systematic studies of mantle xenocrysts have provided additional information on the mantle section (Lehtonen et al., 2004; Lehtonen, 2005a). Three distinct layers (A, B and C) can be identified based on garnet xenocryst compositions and Ni-derived temperatures, when extrapolated to the local geotherm (Kukkonen \& Peltonen, 1999; Kukkonen et al., 2003): (a) A shallow, 60-110 km, garnet-spinel peridotite layer; (b) A variably depleted peridotitic horizon from 110 to $180 \mathrm{~km}$ containing diamond-indicative subcalcic harzbugitic garnet, (c) A deep layer, $>180 \mathrm{~km}$, composed largely of fertile peridotites.

Layer $A$ is distinguished by enigmatic CCGE garnets (named after clinopyroxene-chromite-garnetequilibrium by Kopylova et al., 2000) that are depleted with respect to $\mathrm{Ti}, \mathrm{Y}, \mathrm{Zr}$ and REE but fertile in their major element compositions, as demonstrated by elevated Ca contents. Layer A peridotites have "ultradepleted" arc mantle -type compositions, and have been metasomatised by radiogenic ${ }^{187} \mathrm{Os} /{ }^{188} \mathrm{Os}$, presumably as a result of metasomatism by slab-derived fluids (Peltonen \& Brügmann, 2006). Layer A does not exist at the core of the craton and is thought to represent predominantly Proterozoic arc complex lithosphere. Nevertheless, it has maximum $\mathrm{T}_{\mathrm{RD}}$ ages 
of $-2.6 \mathrm{Ga}$, suggesting at least some Archean material exists within the layer (Peltonen $\&$ Brügmann, 2006). Layer A has a sharp lower contact against Layer $\mathrm{B}$, interpreted as a shear zone along which Layer A was thrust beneath the Karelian Craton margin crust during $-1.9 \mathrm{Ga}$ continental collision (Peltonen \& Brügmann, 2006).

Layer $B$ is considered to represent the least modified SCLM in this cross-section, stabilized during the Paleoarchean. Xenoliths from this horizon are characterized by unradiogenic Os isotopic compositions. ${ }^{187} \mathrm{Os} /{ }^{188} \mathrm{Os}$ shows a good correlation with indices of partial melting implying an age of $-3.3 \mathrm{Ga}$ for komatiite extraction (Peltonen \& Brügmann, 2006), a likely marker of extensive high pressure melting that is postulated to have left these and similar depleted cratonic peridotites worldwide as residues (Boyd, 1989; Griffin et al., 2009). Significantly, this age corresponds closely with the oldest formation ages of the overlying crust (Mutanen \& Huhma, 2003). Subcalcic harzburgitic garnets (G10) with depleted contents of Ti, Y, Zr and HREE exist only in Layer B. In contrast, the lherzolitic garnets (G9) are mostly Tirich and have $\mathrm{REE}_{\mathrm{N}}$ patterns typical of Ca-saturated mantle garnets (e.g., Shimizu, 1975). This was likely caused by a metasomatic re-enrichment event as a result of interaction with silicate melts (cf. Griffin et al., 1989b; Stachel et al., 1998) close in composition to megacryst-forming magmas (Burgess \& Harte, 1999, 2004). Abundant Ti-rich megacrystal garnets attest to the presence and polybaric fractionation of such magmas. However, the existence of harzburgitic and some Ti-poor lherzolitic pyropes requires that some portions of this Archean mantle remained unaffected by melt interaction.

Layer $C$, at depths greater than $180 \mathrm{~km}$, contains no G10 garnets, and is dominated by Ti-rich peridotite pyropes (G11). Significantly however, there exist a few Ti-poor, trace-element depleted G9 pyropes from this layer that possibly represent remnants of Layer B that once extended to greater depths. The osmium isotopic composition of the Layer $\mathrm{C}$ xenoliths is more radiogenic compared to Layer $\mathrm{B}$, yielding only Proterozoic $\mathrm{T}_{\mathrm{RD}}$ ages (Peltonen \& Brügmann, 2006), and is interpreted to represent a melt-metasomatised equivalent to Layer B that was injected by melts c. $2.0 \mathrm{Ga}$ during break-up of the Archean craton.

\section{I.2 The aim of this study}

The aim of this study is to extend the dataset on the SCLM transect from the edge of the Karelian Craton at Kaavi-Kuopio to the Central Karelian Craton by studying mantle-derived materials from Kuhmo, Lentiira, southern Kuusamo (S-Kuusamo) and northern Kuusamo (N-Kuusamo) kimberlites. The working methods are similar to those used in the Kaavi-Kuopio study (Lehtonen, 2005b). However, because only a relatively small volume of hard-rock kimberlite is available from the central craton kimberlites, and because mantle xenoliths appear to be less common in some of these rocks, this work must rely solely on mantle xenocryst data. For comparison purposes, Kaavi-Kuopio data are presented throughout the paper side by side with the new datasets. Summary diagrams of some of the Kuhmo data presented in this study have been published elsewhere (O'Brien et al., 2003).

\section{Samples}

Xenocryst samples from the Lentiira-Kuhmo area are from the Seitaperä (Dyke 16) and Rantala kimberlites and from heavy mineral concentrates taken from till samples. The Kuusamo samples represent xenocrysts from four southern Kuusamo kimberlites, Kalettomanpuro, Kattaisenvaara, Käsmä 45 and Käsmä 47, and one northern Kuusamo kimberlite. Rantala and Lentiira samples were made available to this study by Kopane Diamond Developments Plc, southern Kuusamo samples by Sunrise Diamonds Plc, and northern Kuusamo samples by Mantle Diamonds Ltd. and Kopane Diamond Developments.

In the case of kimberlite rock samples, xenocryst grains $(0.25-2.0 \mathrm{~mm})$ were liberated by lightly crushing the kimberlite material, followed by heavy medium separation, and hand picking. The processing of till samples is described in Lehtonen et al. (2005). Hundreds of garnet and clinopyroxene (cpx) xenoc- 
Table I. Representative electron microprobe and LA-ICP-MS analyses of garnet xenocrysts from the KuhmoLentiira kimberlites.

\begin{tabular}{|c|c|c|c|c|c|c|c|c|c|c|c|c|c|c|c|}
\hline \multirow[b]{2}{*}{$\begin{array}{l}\text { Sample } \\
\text { ID }\end{array}$} & \multirow[b]{2}{*}{ Kimberlite } & \multirow[b]{2}{*}{\begin{tabular}{|l|}
$\begin{array}{l}\text { Garnet } \\
\text { type* }\end{array}$ \\
\end{tabular}} & \multicolumn{10}{|c|}{ EPMA analyses } & \multicolumn{3}{|c|}{ LA-ICP-MS analyses } \\
\hline & & & $\begin{array}{l}\mathrm{SiO} 2 \\
\text { wt. } \% \\
\end{array}$ & $\begin{array}{l}\text { TiO2 } \\
\text { wt. } \% \\
\end{array}$ & \begin{tabular}{|l|}
$\mathrm{Al} 2 \mathrm{O} 3$ \\
$\mathrm{wt} . \%$
\end{tabular} & $\begin{array}{l}\mathrm{Cr} 2 \mathrm{O} 3 \\
\mathrm{wt} \% \\
\end{array}$ & $\begin{array}{l}\mathrm{FeO} \\
\text { wt. } \% \\
\end{array}$ & $\begin{array}{l}\mathrm{MnO} \\
\text { wt. } \%\end{array}$ & \begin{tabular}{|l|}
$\mathrm{MgO}$ \\
wt. $\%$ \\
\end{tabular} & \begin{tabular}{|l|}
$\mathrm{CaO}$ \\
wt. $\%$ \\
\end{tabular} & $\begin{array}{l}\mathrm{Na} 2 \mathrm{O} \\
\text { wt. } \% \\
\end{array}$ & $\begin{array}{l}\text { Total } \\
\text { wt. } \%\end{array}$ & Sc ppm & Ni ppm & Ga ppm \\
\hline 901.02 & & G1 & 41.52 & 0.89 & 22.17 & 0.27 & 9.48 & 0.24 & 20.38 & 4.36 & 0.07 & 99.44 & 60 & 66 & 16.2 \\
\hline 396.02 & EITAPERÄ & $9 \mathrm{~A}$ & 40.88 & 0.03 & 19.83 & 5.34 & 6.91 & 0.36 & 20.21 & 5.61 & 0.00 & 9.17 & 116 & 31 & 2.1 \\
\hline 21.02 & EITAPERÄ & $9 \mathrm{~A}$ & 41.19 & 0.17 & 20.60 & 3.64 & 7.39 & 0.36 & 20.61 & 4.92 & 0.03 & 98.94 & 98 & 38 & 6.1 \\
\hline 0715.02 & EITAPERÄ & G9A & 41.45 & 0.22 & 20.58 & 3.81 & 7.18 & 0.36 & 21.03 & 4.85 & 0.06 & & 99 & 41 & 7.5 \\
\hline 220.02 & ITAPERÄ & $9 \mathrm{~A}$ & 40.72 & 0.22 & 20.79 & 3.88 & 7.42 & 0.35 & 20.99 & 4.96 & 0.03 & & 87 & 47 & 7.8 \\
\hline 240.02 & ITAPERÄ & & 40.05 & & & & & & 20.81 & 5.35 & & & & & 6.1 \\
\hline & EITAPERÄ & & & & & & & & 20.98 & 5.39 & & & & & 5.8 \\
\hline & ITAPERÄ & & & & & & & & & & & & & & 7.3 \\
\hline & $R \ddot{A}$ & & & & & & & & & 5.01 & & & & & 7.2 \\
\hline & ITAPERÄ & & 41.05 & & & 5.16 & 6.59 & 0.33 & 21.05 & 5.39 & .03 & & & 83 & 6.2 \\
\hline 314.02 & EITAPERÄ & & 41.68 & 0.24 & & 4.72 & 5.85 & 0.24 & 22.06 & 5.00 & .03 & .74 & 105 & & 7.1 \\
\hline 327.02 & SEITAPERÄ & $9 \mathrm{~A}$ & 41.28 & & 18.23 & 6.47 & 5.94 & 0.23 & 20.92 & 5.66 & 0.01 & 3.89 & & 01 & 5.8 \\
\hline 328.02 & SEITAPERÄ & G9A & 42.00 & 0.19 & 19.95 & 4.71 & 5.73 & 0.26 & 22.07 & 5.02 & 0.02 & 9.99 & 104 & & 6.7 \\
\hline & SEITAPERÄ & & & & & & 5.39 & & 21.37 & 5.59 & & & & & 5.1 \\
\hline & $\mathrm{RÄ}$ & & & & & & & & & & & & & & 4.1 \\
\hline & & & & & & & & & & & & & & & 7.7 \\
\hline & & & & & & & & & & & & & & & 2.2 \\
\hline & & & & & & & & & & & & & & & 2.2 \\
\hline & & & & & & & & & & & & & & & 1.0 \\
\hline & EITAPERÄ & & & & & & & & & & & & & & 2.8 \\
\hline 0694.02 & EITAPERÄ & 11 & 41.79 & 032 & 20.57 & 311 & 5.92 & 0.28 & 22.21 & 4.69 & 04 & & & 22 & 2.9 \\
\hline 392.02 & SEITAPERÄ & & 42.02 & 0.44 & 20.82 & 3.40 & 6.07 & & 22.05 & 4.69 & & & 9 & & 7.1 \\
\hline & SEITAPERÄ & & & & & & & & & 4.80 & & & 78 & & 7.5 \\
\hline & & & & & & & & & & & & & & & 8.5 \\
\hline & & & & & & & & & & & & & & & 6.3 \\
\hline & & & & & & & & & & & & & & & 7.4 \\
\hline & & & & & & & & & & & & & & & \\
\hline & ANTALA & & & & & & 5.92 & & & & & & & & 0.6 \\
\hline 10746.02 & RANTALA & & & & & & 5.17 & & 22.78 & & & & & & 2.2 \\
\hline & & & & & & & & & & & & & & 103 & 3.4 \\
\hline & & & & & & & & & & & & & & & 6.1 \\
\hline & & & & & & & & & & & & & & 84 & 5.6 \\
\hline & & & & & & & & & & & & & & & 7.3 \\
\hline & & & & & & & & & & & & & & & 0.8 \\
\hline & LENTIIRA & G9A & & & & & & & 21.15 & & 0.00 & 100.16 & 116 & 69 & 3.5 \\
\hline & LENTIIRA & G9A & & & & & 6.33 & 0.34 & 21.54 & & 0.03 & 100.45 & 87 & 29 & 5.2 \\
\hline & LENTIIRA & G9A & & & & & 6.43 & & 21.39 & & & & 101 & 50 & 5.5 \\
\hline & & G9B & & & & & & & & & & & & 21 & 2.3 \\
\hline & LENTIIRA & & & & & & & & & & & & & 116 & 1.4 \\
\hline 9901.00 & LENTIIRA & & 40.62 & & & & 5.74 & 0.29 & 22.39 & 3.77 & 0.05 & 99.27 & & 85 & 1.4 \\
\hline 7540.00 & LENTIIRA & G10B & 40.50 & 0.06 & & & 6.82 & 0.38 & 20.90 & 4.99 & 0.00 & 99.28 & 123 & 49 & 3.5 \\
\hline 7603.00 & LENTIIRA & G11 & 41.72 & 0.49 & 21.62 & 2.50 & 6.80 & 0.30 & 21.79 & 4.32 & 0.06 & 99.70 & 80 & 49 & 8.4 \\
\hline 9922.00 & ENTIIRA & G11 & 40.28 & 1.01 & 17.56 & 6.50 & 6.50 & 0.23 & 20.55 & 5.79 & 0.03 & 98.47 & 111 & 98 & 6.1 \\
\hline
\end{tabular}

*) Garnet type after Grütter et al., $2004{ }^{* *}$ ) RGP96 = Ryan et al., 1996

n.a. = not analyzed

n.d. = not detected 


\begin{tabular}{|c|c|c|c|c|c|c|c|c|c|c|c|c|c|}
\hline Y ppm & Zr ppm & La ppm & Ce ppm & Pr ppm & $\mathrm{Nd}$ ppm & Sm ppm & Eu ppm & Gd ppm & Dy ppm & Er ppm & $\mathrm{Yb}$ ppm & Lu ppm & $\begin{array}{l}\mathrm{TNi}\left(\mathrm{C}^{\circ}\right) \\
\mathrm{RGP}^{* *}\end{array}$ \\
\hline 17.7 & 110.3 & 0.03 & 0.57 & 0.20 & 1.80 & 1.18 & 0.50 & 1.68 & 2.82 & 2.04 & 1.94 & 0.27 & 1125 \\
\hline 0.3 & 3.8 & 0.31 & 1.79 & 0.36 & 1.46 & 0.04 & 0.02 & 0.12 & 0.20 & 0.10 & 0.44 & 0.13 & 894 \\
\hline 10.9 & 8.1 & 14 & 31 & 10 & 68 & 41 & 19 & .84 & 36 & 1.21 & .52 & 26 & 45 \\
\hline 11.4 & 9.4 & 54 & 1.16 & 0.20 & 1.20 & 0.56 & 0.15 & 0.67 & 1.96 & 1.23 & 1.48 & 0.26 & 973 \\
\hline 10.5 & 8.0 & 0.97 & 2.31 & 0.40 & 1.96 & 0.73 & 0.21 & 0.87 & 1.66 & 1.15 & 1.48 & 0.20 & 1008 \\
\hline 2.9 & 39.4 & 0.17 & 63 & 0.29 & 2.44 & 0.84 & .27 & 0.65 & 0.63 & 0.48 & 0.30 & n.d & 1188 \\
\hline 3.0 & 42.3 & 0.17 & 0.51 & 0.77 & 1.99 & 0.65 & 0.21 & 0.54 & 0.79 & 0.39 & 0.36 & n.d & 1203 \\
\hline 7.0 & 8.1 & 0.03 & 0.93 & 0.30 & 2.34 & 0.59 & 3 & 0.70 & 0.94 & 0.96 & 0.75 & 0.17 & 1206 \\
\hline 6.8 & 9.9 & 0.14 & 1.10 & 0.27 & 2.13 & 0.65 & 0.28 & 0.44 & 1.30 & 1.08 & 0.43 & 0.17 & 1209 \\
\hline 3.0 & 36.4 & 23 & 0.66 & 0.28 & 2.38 & 0.52 & 28 & 0.48 & 0.51 & 0.45 & 0.15 & 0.00 & 1216 \\
\hline 7.4 & 7.3 & 20 & 1.17 & 0.17 & 1.79 & 0.30 & 0.15 & 0.46 & 1.02 & 0.89 & 0.86 & 0.16 & 1230 \\
\hline 3.2 & 8.3 & 0.65 & 2.49 & 0.35 & 2.66 & 0.84 & 0.20 & 0.35 & 0.65 & 0.52 & 0.56 & 0.16 & 1255 \\
\hline 8.2 & 18.6 & 11 & n.d & & 78 & 04 & & 7 & 1.43 & 94 & 1.11 & 15 & 270 \\
\hline 8.9 & 14.1 & 0.23 & 1.14 & 0. & 2.56 & 85 & 34 & 1.07 & 1.62 & 0.99 & 1.14 & 0.29 & 1296 \\
\hline 10.6 & 14.1 & 0.02 & 11 & 0.04 & 0.63 & 0.46 & 0.28 & 0.84 & 1.60 & 1.19 & 1.50 & 0.22 & 805 \\
\hline 11.1 & 7.8 & 0. & & & 16 & & & 46 & 3 & 4 & 0 & 0 & 64 \\
\hline 0.6 & 1.1 & 0.55 & 5.51 & 1.27 & 3 & 17 & 0.05 & 0.01 & 0.01 & 0.03 & 0.30 & 16 & 26 \\
\hline 0.8 & 1.4 & 0.73 & 64 & 1.26 & 4.30 & 0.03 & 0.01 & 0.07 & 0.12 & 0.13 & 0.58 & 0.19 & 955 \\
\hline 0. & 3.2 & & & & 2.30 & & & 13 & 7 & 0.20 & 0.19 & 04 & 81 \\
\hline 2. & 2.8 & 0.09 & 1.32 & 0.35 & 2.13 & 7 & 4 & 0.45 & 0.48 & 0.17 & 0.51 & 20 & 1279 \\
\hline 1.0 & 8.9 & & 3.02 & 0.54 & 2.86 & 0.59 & 0.15 & 0.10 & 0.19 & 0.16 & 0.16 & 18 & 914 \\
\hline 14.8 & 32.5 & 0.04 & 1 & 0 & 1.39 & 0.66 & 6 & 1.13 & 2.14 & 1.57 & 2.12 & 0.33 & 1219 \\
\hline 11.9 & 30.4 & 0 & 0 & 4 & 1.37 & 45 & 7 & 1.20 & 1.87 & 1.72 & 1.66 & 18 & 230 \\
\hline 14.3 & & & & 0 & 1.60 & 30 & 2 & 1.37 & 2.57 & 2.07 & 1.86 & 0.29 & 1246 \\
\hline 15.5 & & & & & & & & 1. & 2.8 & 1.45 & 2.21 & 39 & 1290 \\
\hline 12.5 & 30.4 & 0.21 & 55 & 0.43 & 3.31 & 1.21 & 0.46 & 1.82 & 2.21 & 1.47 & 1.59 & .29 & 1350 \\
\hline 42.7 & 370.3 & 0.05 & 0.63 & 0.26 & 2.61 & 2.04 & 1.03 & 4.19 & 6.59 & 5.13 & 6.06 & 0.83 & 888 \\
\hline 1.7 & & & 1.19 & 0. & & & & 1.02 & 0.86 & 0.10 & n.d. & 0.08 & 374 \\
\hline 2.6 & & & & & 4.20 & & 4 & 1.18 & 0.58 & 0.17 & 0.24 & 0.03 & 1257 \\
\hline 2.9 & 67.3 & $\pi$ & 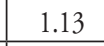 & 0.44 & 07 & 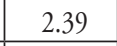 & 0 & 3 & 0.63 & 22 & 0.36 & 06 & 314 \\
\hline 9. & & & 1.07 & & & & & 1.62 & 1.54 & 2 & 0.98 & 18 & 1203 \\
\hline 9.1 & 62.6 & 05 & & 0. & 3.82 & & & 1.16 & 1.46 & 0.94 & 1.40 & 0.22 & 1223 \\
\hline 10.4 & 122.7 & 0.15 & 0.71 & 0.26 & 2.59 & 1.48 & 0.63 & 2.08 & 2.66 & 0.92 & 0.67 & 0.13 & 1274 \\
\hline 18.7 & 72.7 & 0.14 & 9.59 & 0.23 & 1.69 & 1.12 & 0.61 & 1.75 & 3.24 & 2.24 & 2.28 & 0.41 & 1434 \\
\hline 0.9 & 14.7 & 0.15 & 116 & 0.41 & 3.97 & 0.18 & 0.05 & 0.27 & 0.05 & 0.15 & 0.32 & 0.09 & 1145 \\
\hline 9.8 & 9.4 & n.d & & n.d. & 0.7 & 45 & 0.31 & 0.71 & 1.25 & 1.10 & 1.25 & 0.20 & 873 \\
\hline 8.8 & 53.5 & n.d & 0.13 & 0.07 & 0.8 & 0.85 & 0.36 & 1.20 & 1.49 & 1.08 & 1.24 & 0.20 & 1029 \\
\hline $3 .($ & 10.7 & & & 0.02 & 1.07 & 0.94 & 0.39 & 1.34 & 1.04 & 0.36 & 0.18 & n.d. & 797 \\
\hline 2.3 & 6.5 & 0.48 & 3.70 & 0.84 & 3.79 & 4 & 0.09 & 0.48 & 0.38 & 0.44 & 0.45 & 0.12 & 1373 \\
\hline 0.8 & 73.7 & 0.07 & 1.21 & 0.34 & 3.0 & 1.17 & 0.35 & 0.96 & 0.41 & 0.14 & 0.21 & n.d & 1228 \\
\hline 2.5 & 2.6 & n.d & 1.07 & 0.31 & 2.37 & 0.13 & -0.00 & 0.39 & 0.32 & 0.32 & 0.66 & 0.06 & 1025 \\
\hline 17.7 & & & - & n.d. & 0.86 & 48 & 0.43 & 1.5 & 2.73 & 1.96 & 2.28 & 0.33 & 1024 \\
\hline 10.3 & 149.9 & 0.18 & 1.24 & 0.32 & 2.6 & 1.88 & 0.75 & 2.54 & 2.64 & 0.89 & 0.77 & 0.15 & 1292 \\
\hline
\end{tabular}


Table 2. Representative electron microprobe analyses of garnet xenocrysts from the Kuusamo kimberlites.

\begin{tabular}{|c|c|c|c|c|c|c|c|}
\hline \multirow[b]{2}{*}{ Sample ID } & \multirow[b]{2}{*}{ Kimberlite } & \multirow[b]{2}{*}{ Garnet type* } & \multicolumn{5}{|c|}{ EPMA analyses } \\
\hline & & & SiO2 wt. $\%$ & TiO2 wt.\% & $\mathrm{Al} 2 \mathrm{O} 3$ wt. $\%$ & Cr2O3 wt. $\%$ & FeO wt.\% \\
\hline 7014.06 & Käsmä 45 & G11 & 41.95 & 1.03 & 17.90 & 4.60 & 7.19 \\
\hline 7021.06 & Käsmä 45 & G11 & 40.29 & 1.01 & 17.70 & 5.98 & 7.15 \\
\hline$\underline{7018.06}$ & Käsmä 45 & G9A & 41.89 & 0.09 & 20.39 & 3.87 & 6.35 \\
\hline 13914.05 & Käsmä 47 & G9A & 41.40 & 0.04 & 15.83 & 9.70 & 5.93 \\
\hline 13916.05 & Käsmä 47 & G10A & 41.15 & 0.05 & 16.09 & 9.33 & 5.86 \\
\hline 13968.05 & Käsmä 47 & G11 & 42.07 & 0.95 & 18.79 & 4.48 & 6.51 \\
\hline 9802.04 & \begin{tabular}{|l|} 
Kalettomanpuro \\
\end{tabular} & G1 & 41.95 & 0.52 & 22.90 & 0.50 & 8.09 \\
\hline 9808.04 & Kalettomanpuro & G1 & 41.66 & 0.47 & 22.76 & 0.51 & 8.52 \\
\hline 9785.04 & Kalettomanpuro & G9A & 41.52 & 0.15 & 19.52 & 5.29 & 6.79 \\
\hline 9786.04 & Kalettomanpuro & G9A & 41.82 & 0.19 & 19.22 & 5.76 & 5.87 \\
\hline 9798.04 & Kalettomanpuro & G9B & 42.15 & 0.02 & 21.31 & 3.41 & 5.90 \\
\hline 9765.04 & Kalettomanpuro & G9A & 41.44 & 0.19 & 19.39 & 5.62 & 5.85 \\
\hline 9769.04 & Kalettomanpuro & G9A & 41.68 & 0.29 & 18.91 & 6.38 & 5.96 \\
\hline 9758.04 & Kalettomanpuro & G9B & 41.15 & 0.08 & 17.34 & 8.23 & 5.75 \\
\hline 9771.04 & Kalettomanpuro & G10A & 42.18 & 0.01 & 20.96 & 3.85 & 5.49 \\
\hline 9759.04 & Kalettomanpuro & G10A & 42.29 & 0.02 & 21.19 & 3.79 & 5.53 \\
\hline 9755.04 & Kalettomanpuro & G10A & 42.02 & 0.15 & 18.80 & 6.67 & 5.84 \\
\hline 9766.04 & Kalettomanpuro & G10A & 42.28 & 0.02 & 21.97 & 2.96 & 5.42 \\
\hline 9761.04 & Kalettomanpuro & G11 & 42.07 & 0.34 & 20.15 & 4.62 & 6.06 \\
\hline 9789.04 & Kalettomanpuro & G11 & 42.01 & 0.68 & 20.44 & 3.31 & 7.68 \\
\hline 12413.04 & Kattaisenvaara & G9A & 40.91 & 0.06 & 19.53 & 5.33 & 6.42 \\
\hline 12372.04 & Kattaisenvaara & G9B & 41.19 & 0.02 & 19.89 & 5.08 & 6.36 \\
\hline 12365.04 & Kattaisenvaara & G9B & 40.72 & 0.12 & 17.71 & 7.69 & 7.17 \\
\hline 12410.04 & Kattaisenvaara & G9A & 40.51 & 0.02 & 19.18 & 5.48 & 6.22 \\
\hline 12408.04 & Kattaisenvaara & G9A & 40.99 & 0.24 & 19.70 & 4.63 & 6.28 \\
\hline 12407.04 & Kattaisenvaara & G11 & 40.90 & 0.67 & 19.25 & 4.60 & 6.35 \\
\hline 12309.04 & Kattaisenvaara & G11 & 41.05 & 0.82 & 16.83 & 7.43 & 6.62 \\
\hline 9018-POH-02 & N. Kuusamo & G1 & 41.82 & 0.56 & 21.37 & 2.40 & 7.19 \\
\hline 9001-PIN-02 & N. Kuusamo & G1 & 40.74 & 0.61 & 21.74 & 1.79 & 7.66 \\
\hline $\mathrm{D} 478$ & N. Kuusamo & G1 & 41.58 & 0.77 & 22.68 & 0.28 & 7.73 \\
\hline 9069-POH-02 & N. Kuusamo & G10A & 40.25 & 0.00 & 18.81 & 6.64 & 6.23 \\
\hline$\underline{\mathrm{D} 478}$ & N. Kuusamo & G10A & 40.62 & 0.09 & 17.31 & 8.60 & 6.10 \\
\hline$\underline{\mathrm{D} 478}$ & N. Kuusamo & G10A & 40.88 & 0.12 & 17.24 & 8.93 & 5.94 \\
\hline 9196-KES-02 & N. Kuusamo & G10A & 40.61 & 0.07 & 18.06 & 7.93 & 5.99 \\
\hline$\underline{\mathrm{D} 478}$ & N. Kuusamo & G10A & 41.77 & 0.00 & 20.16 & 5.26 & 5.77 \\
\hline $\mathrm{D} 478$ & N. Kuusamo & G10A & 41.84 & 0.02 & 20.22 & 5.31 & 6.01 \\
\hline 9034-KES-02 & N. Kuusamo & G10A & 40.76 & 0.24 & 17.37 & 8.30 & 6.33 \\
\hline 9059-POH-02 & N. Kuusamo & G11 & 40.79 & 0.52 & 19.29 & 4.93 & 6.64 \\
\hline 9295-KES-03 & N. Kuusamo & G11 & 41.28 & 0.64 & 21.96 & 2.21 & 6.97 \\
\hline 9083-KES-02 & N. Kuusamo & G11 & 41.36 & 0.51 & 19.63 & 5.06 & 6.04 \\
\hline 9001-PIN-02 & N. Kuusamo & G11 & 41.36 & 0.44 & 19.69 & 4.79 & 6.69 \\
\hline 9043-POH-02 & N. Kuusamo & G9A & 40.69 & 0.33 & 18.89 & 6.00 & 6.49 \\
\hline $\mathrm{D} 478$ & N. Kuusamo & G9A & 41.32 & 0.26 & 20.55 & 4.25 & 6.24 \\
\hline$\underline{\mathrm{D} 478}$ & N. Kuusamo & G9A & 40.40 & 0.20 & 17.55 & 8.07 & 6.28 \\
\hline $\mathrm{D} 478$ & N. Kuusamo & G9A & 41.70 & 0.21 & 21.09 & 3.68 & 5.88 \\
\hline$\underline{\mathrm{D} 478}$ & N. Kuusamo & G9A & 41.07 & 0.18 & 21.11 & 3.34 & 6.11 \\
\hline 9039-POH-02 & N. Kuusamo & G9A & 40.87 & 0.25 & 20.55 & 3.65 & 6.93 \\
\hline 035-KUU-00 & N. Kuusamo & G9A & 41.42 & 0.19 & 20.89 & 3.83 & 6.05 \\
\hline 9066-KES-02 & N. Kuusamo & G9B & 39.99 & 0.22 & 17.62 & 8.11 & 6.95 \\
\hline
\end{tabular}

*) Garnet type after Grütter et al., $2004^{* *}$ ) RGP96 = Ryan et al., 1996 


\begin{tabular}{|c|c|c|c|c|c|c|c|c|}
\hline & & & & & trace data & & & \\
\hline $\mathrm{MnO}$ wt. $\%$ & $\mathrm{MgO}$ wt. $\%$ & $\mathrm{CaO}$ wt. $\%$ & $\mathrm{Na} 2 \mathrm{O}$ wt. $\%$ & Total wt. $\%$ & Ti ppm & Mn ppm & Ni ppm & TNi $\left(\mathrm{C}^{\circ}\right) \mathrm{RGP}^{* * *}$ \\
\hline 0.32 & 20.86 & 5.62 & 0.10 & 99.63 & 5680 & 2259 & 86 & 1230 \\
\hline 0.28 & 20.93 & 5.77 & 0.13 & 99.30 & 5615 & 2262 & 105 & 1323 \\
\hline 0.26 & 21.98 & 5.16 & 0.00 & 100.05 & 295 & 1881 & 125 & 1412 \\
\hline 0.09 & 20.94 & 5.80 & 0.02 & 99.80 & 215 & 2116 & 118 & 1379 \\
\hline 0.05 & 21.09 & 5.67 & 0.02 & 99.35 & 215 & 2099 & 117 & 1377 \\
\hline 0.16 & 21.75 & 5.24 & 0.09 & 100.17 & 5536 & 1893 & 119 & 1386 \\
\hline 0.27 & 21.10 & 4.41 & 0.04 & 99.87 & 4490 & 2340 & 51 & 1037 \\
\hline 0.34 & 21.34 & 4.15 & 0.06 & 99.87 & 2421 & 2446 & 66 & 1127 \\
\hline 0.36 & 21.16 & 4.70 & 0.04 & 99.61 & 648 & 2764 & 45 & 998 \\
\hline 0.28 & 21.53 & 5.24 & 0.02 & 99.98 & 965 & 2127 & 60 & 1092 \\
\hline 0.27 & 21.69 & 5.18 & 0.00 & 100.00 & 85 & 1964 & 64 & 1115 \\
\hline 0.27 & 21.41 & 5.26 & 0.01 & 99.53 & 939 & 2138 & 69 & 1143 \\
\hline 0.25 & 20.97 & 5.81 & 0.02 & 100.27 & 1500 & 1983 & 74 & 1170 \\
\hline 0.29 & 20.00 & 6.41 & 0.01 & 99.34 & 346 & 2175 & 76 & 1181 \\
\hline 0.26 & 23.01 & 3.92 & 0.02 & 99.75 & 79 & 1887 & 61 & 1098 \\
\hline 0.26 & 23.20 & 3.91 & 0.01 & 100.23 & 79 & 1872 & 67 & 1132 \\
\hline 0.26 & 21.79 & 4.91 & 0.02 & 100.50 & 736 & 2053 & 70 & 1149 \\
\hline 0.24 & 24.04 & 3.20 & 0.01 & 100.18 & 92 & 1713 & 76 & 1181 \\
\hline 0.25 & 21.56 & 5.04 & 0.04 & 100.22 & 1794 & 2009 & 74 & 1170 \\
\hline 0.26 & 20.94 & 5.22 & 0.03 & 100.61 & 3569 & 1874 & 105 & 1323 \\
\hline 0.33 & 21.10 & 5.46 & 0.03 & 99.26 & 714 & 3258 & 12 & 691 \\
\hline 0.34 & 20.98 & 5.67 & 0.01 & 99.63 & 72 & 3105 & 19 & 780 \\
\hline 0.44 & 18.55 & 7.10 & 0.00 & 99.59 & 738 & 3441 & 29 & 872 \\
\hline 0.30 & 21.05 & 5.13 & 0.02 & 97.97 & 174 & 2366 & 41 & 970 \\
\hline 0.27 & 21.88 & 5.00 & 0.03 & 99.18 & 1411 & 2103 & 84 & 1222 \\
\hline 0.25 & 21.55 & 5.20 & 0.05 & 98.93 & 3848 & 1920 & 105 & 1321 \\
\hline 0.28 & 20.51 & 6.22 & 0.06 & 99.93 & 5420 & 2136 & 110 & 1343 \\
\hline 0.24 & 21.61 & 4.22 & 0.07 & 99.64 & 722 & 2489 & 53 & 1050 \\
\hline 0.26 & 21.46 & 4.29 & 0.07 & 98.94 & 1544 & 2202 & 75 & 1176 \\
\hline 0.29 & 22.33 & 4.15 & 0.08 & 100.31 & 3817 & 1918 & 91 & 1257 \\
\hline 0.32 & 23.17 & 2.36 & 0.01 & 98.25 & 723 & 2395 & 54 & 1056 \\
\hline 0.29 & 22.18 & 4.28 & 0.01 & 99.83 & 399 & 2126 & 64 & 1115 \\
\hline 0.26 & 22.31 & 4.14 & 0.01 & 100.16 & 606 & 2070 & 67 & 1132 \\
\hline 0.18 & 23.31 & 2.68 & 0.01 & 99.22 & 2361 & 1964 & 70 & 1149 \\
\hline 0.23 & 24.94 & 1.53 & 0.02 & 100.02 & 104 & 1877 & 74 & 1170 \\
\hline 0.28 & 25.08 & 1.53 & 0.01 & 100.71 & 101 & 1876 & 80 & 1202 \\
\hline 0.35 & 20.96 & 4.57 & 0.03 & 99.18 & 2937 & 2068 & 95 & 1276 \\
\hline 0.28 & 21.16 & 5.16 & 0.09 & 99.21 & 938 & 3061 & 26 & 850 \\
\hline 0.29 & 22.19 & 4.48 & 0.09 & 100.61 & 449 & 2783 & 54 & 1056 \\
\hline 0.29 & 21.84 & 4.77 & 0.05 & 99.75 & 3632 & 2112 & 73 & 1165 \\
\hline 0.28 & 20.91 & 5.26 & 0.04 & 99.72 & 3172 & 2049 & 88 & 1242 \\
\hline 0.26 & 20.88 & 5.45 & 0.04 & 99.35 & 2324 & 2584 & 39 & 956 \\
\hline 0.28 & 22.09 & 4.77 & 0.05 & 100.17 & 1362 & 2030 & 61 & 1098 \\
\hline 0.34 & 20.89 & 5.74 & 0.03 & 99.93 & 1121 & 2153 & 69 & 1143 \\
\hline 0.26 & 22.59 & 4.55 & 0.05 & 100.32 & 994 & 1909 & 71 & 1154 \\
\hline 0.29 & 22.57 & 4.51 & 0.05 & 99.70 & 970 & 1903 & 73 & 1165 \\
\hline 0.24 & 21.23 & 5.08 & 0.05 & 99.14 & 1647 & 2050 & 78 & 1192 \\
\hline 0.28 & 21.79 & 4.83 & 0.03 & 99.37 & 4427 & 2153 & 93 & 1267 \\
\hline 0.40 & 19.66 & 5.83 & 0.03 & 99.12 & 11 & 2311 & 71 & 1154 \\
\hline
\end{tabular}


rysts were recovered from the kimberlite and till concentrates and mounted for analysis. In this study only unsorted garnet concentrates were used in order to gain unbiased populations for each of the kimberlites.

\section{Analytical techniques}

Garnet major element compositions were determined by Cameca SX50 and SX100 electron microprobes (EMP) at the Geological Survey of Finland (GTK), applying an acceleration voltage of $25 \mathrm{kV}$, probe current of $48 \mathrm{nA}$ and beam diameter of $1 \mu \mathrm{m}$. The parameters for clinopyroxene analyses were $15 \mathrm{kV}, 30$ $\mathrm{nA}$ and $5 \mu \mathrm{m}$, respectively. Selected garnet xenocrysts from Lentiira-Kuhmo were analyzed for trace elements by LA-ICP-MS at the University of Cape Town, using the methodology and equipment described in Grégoire et al. (2003). Typical theoretical detection limits are in the range of 10-20 ppb for REE, Zr and Y, and 2 ppm for Ti and Ni. Trace Ni data by EMP were obtained on pyrope grains employing $500 \mathrm{nA}$ probe current, 600s counting times on peak plus background positions and were reduced by the CSIRO TRACE program for the SX50 (Robinson \& Graham, 1992). Cross-checking of the trace methods shows that $\mathrm{Ni}$ analyses in pyrope by EMP can achieve similar precision to those of LA ICP-MS down to a level of ca. $10 \mathrm{ppm}$.

The garnets were classified based on their major element composition into harzburgitic (G10), lherzolitic (G9), wehrlitic (G12), high-Ti peridotitic (G11), lowCr megacrystal (G1), eclogitic (G3, G4), pyroxenitic $(\mathrm{G} 4, \mathrm{G} 5)$, and crustal varieties according to Grütter et al. (2004). For equilibration temperatures the Ni thermometer (Griffin et al., 1989a) was applied using the calibration of Ryan et al. (1996). Equilibration pressures and temperatures of peridotitic clinopyroxene were calculated using the single-grain cpx thermobarometer of Nimis \& Taylor (2000).

\section{Results}

Major and trace element analyses for a large portion of the Kuhmo, Lentiira and Kuusamo samples used in this study are available as an Open File Report (Lehtonen et al., 2008) at the Geological Survey of Finland website (www.gtk.fi). Selected analyses are presented in Tables 1 and 2. Trace element data obtained by LA-ICP-MS is available only from Kuhmo and Lentiira samples.

\section{I Garnet major element geochemistry}

$\mathrm{CaO}$ and $\mathrm{Cr}_{2} \mathrm{O}_{3}$ contents of mantle garnets from Kuopio, Kaavi, Kuhmo, Lentiira, S-Kuusamo and NKuusamo kimberlites are shown in Figure 2. It is evident that lherzolitic garnets (G9) predominate over other garnet varieties in samples from all kimberlite fields and that only a minority classifies as subcalcic harzburgitic grains (G10). Relatively Cr-poor, but Ti-rich, pyropes of megacryst composition (G1) are also common at all localities. Pyrope populations from the edge of the craton (Kaavi-Kuopio) are considerably poorer in harzburgitic pyropes compared to the craton core samples represented by Lentiira-Kuhmo. However, there is a prominent eclogitic component (G3/G4) at Kaavi-Kuopio (grains in the lower right of Fig. 2) that is nearly absent from the Lentiira-Kuhmo mantle and in terms of diamond potential, may compensate for the paucity of G10 source rocks. Fewer grains are available from the $\mathrm{N}$ - and $\mathrm{S}$ Kuusamo locations, but both areas show a relatively high proportion of the harzburgitic to lherzolitic pyropes, suggesting a depleted mantle more similar to that at Lentiira-Kuhmo.

\subsection{Clinopyroxene thermobarometry}

Single-grain thermobarometry from clinopyroxene xenocrysts and clinopyroxene-garnet aggregates from Kaavi-Kuopio kimberlites fits reasonably well with a regional geotherm of $36 \mathrm{~mW} / \mathrm{m}^{2}$ calculated using heat flow constraints, xenolith modes and geophysical properties (Kukkonen \& Peltonen, 1999; Kukkonen et al., 2003). Figure 3 shows the correspondence between the xenolith and xenocryst data and includes reference fields for the Slave Craton from Grütter (2009). 

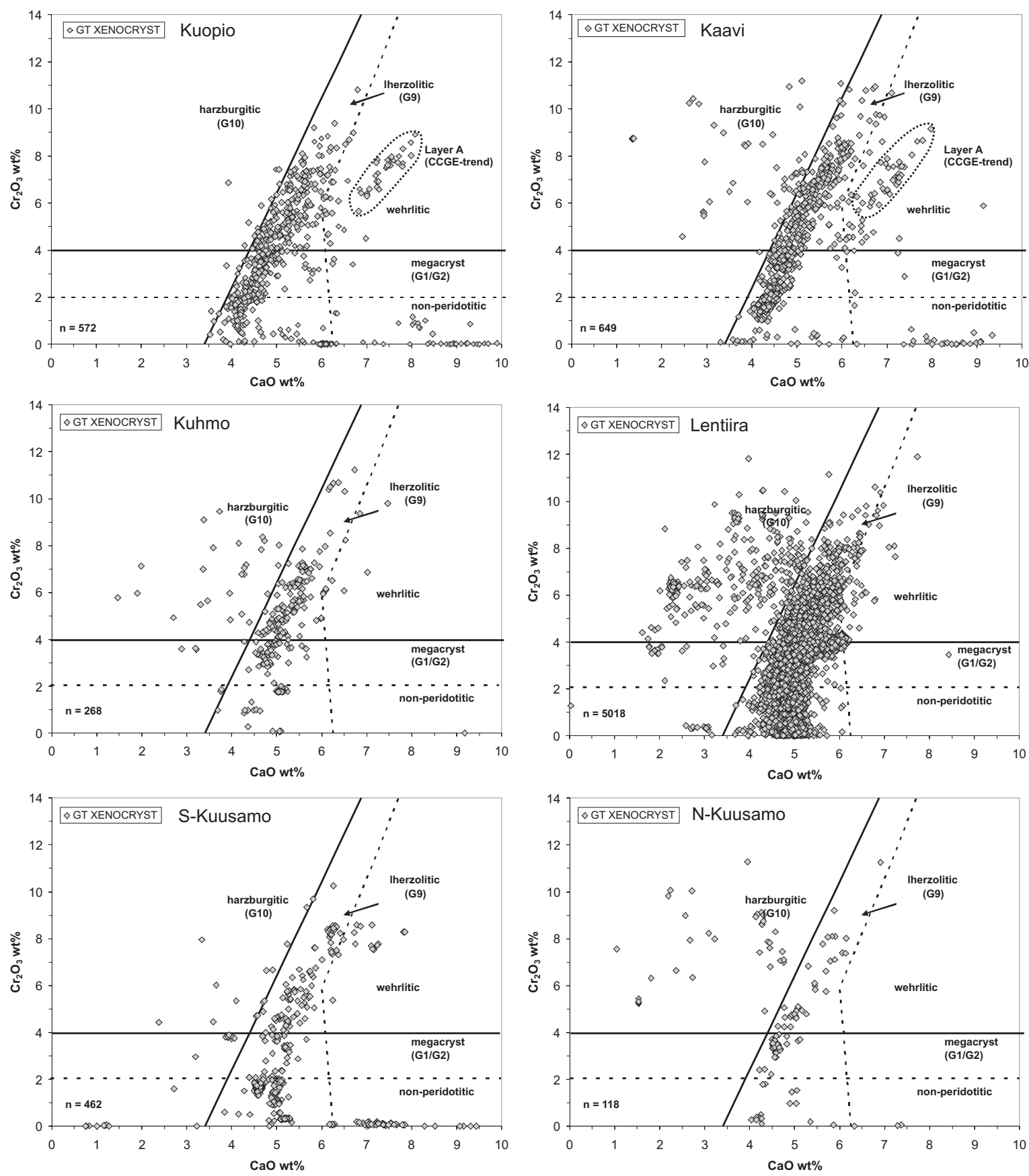

Figure 2. $\mathrm{Cr}_{2} \mathrm{O}_{3}$ vs. $\mathrm{CaO}$ of Kuopio, Kaavi, Kuhmo, Lentiira, and southern and northern Kuusamo kimberlite-derived garnet xenocrysts. Crustal garnets are excluded from this diagram using the classification of Schulze (2003). The harzburgite, Iherzolite and non-peridotite fields are redrawn after Gurney (1984) and the wehrlite field is separated according to Sobolev et al. (1973). Arrow pointing NE in the Kaavi-Kuopio diagram marks the "CCGE" garnet trend, i.e. chromite-clinopyroxene-garnet equilibrium, recognized in spinel-garnet peridotites from the Jericho kimberlite by Kopylova et al. (2000). Layer A explained in text, section I.I. 
Constructing single-clinopyroxene geotherms (after Nimis and Taylor, 2000) for Kuhmo, Lentiira and S-Kuusamo areas has proven much more difficult than for Kaavi-Kuopio because of the rarity of high temperature $\left(>1100{ }^{\circ} \mathrm{C}\right)$ clinopyroxene grains. Their virtual absence is somewhat enigmatic since high temperature lherzolitic garnets are well represented at both localities, suggesting clinopyroxene-bearing source rocks in the deeper parts of the SCLM. However, PT data on clinopyroxenes from xenoliths extracted from ca. 1.2 Ga Group II-olivine lamproite dike rocks from Kostomuksha that are mineralogical and compositional analogues and time correlative to the Lentiira-Kuhmo rocks, provide evidence that the lithospheric mantle at this time, in this part of the world had a cold geotherm similar to that at KaaviKuopio (Antonov \& Ulianov, 2008).

Although not abundant, our N-Kuusamo samples did contain sufficient mantle-derived clinopyroxene grains from which the local geotherm could be defined. In Figure 3 the data are plotted against the Kaavi-Kuopio data, and it can be seen that there is only a minimal difference between the two single-cpx-based geotherms and that they deviate approximately the same amount from the more accurately defined Kaavi-Kuopio xenolith geotherm of Kukkonen \& Peltonen (1999). Consequently, we have used the xenolith-based geotherm for all Central Karelian data, including Kuhmo, Lentiira and S-Kuusamo.

\subsection{Garnet thermometry and trace element geochemistry}

\subsection{I $T_{N i}$ histograms}

$\mathrm{T}_{\mathrm{Ni}}$ histograms for Kaavi, Kuopio, Kuhmo, Lentiira, $\mathrm{S}$ - and N-Kuusamo garnet xenocrysts are presented in Figure 4a. Megacryst garnets (G1) with $\mathrm{Cr}_{2} \mathrm{O}_{3}$ $>1.5$ wt. $\%$ and $\mathrm{MgO}>18$ wt. $\%$ are included in the diagrams for illustrative purposes, based on the reasoning that they reach the same contents of $\mathrm{Cr}_{2} \mathrm{O}_{3}$ and $\mathrm{MgO}$ as do the $\mathrm{G} 9$ pyropes, implying equilibration with olivine similar in composition to that in the lherzolites. The megacryst temperatures give rea- sonable results, however the coexisting olivine may have lower $\mathrm{Ni}$ than normal peridotite and in that case the megacryst temperatures would be underestimated.

The Kaavi-Kuopio data show a bimodal distribution including a strong low temperature peak at 700 to $850^{\circ} \mathrm{C}$ (Layer A) consisting dominantly of CCGE pyropes, that are classified either as wehrlitic (G12) or lherzolitic (G9) varieties according to Grütter et al. (2004), and a stronger abundance peak at 1000 to $1150^{\circ} \mathrm{C}$ (Layer B) consisting of lherzolitic (G9), harzburgitic (G10), high-Ti peridotitic (G11), wehrlitic (G12) and megacryst (G1) varieties. $1150{ }^{\circ} \mathrm{C}$ separates mantle containing strongly depleted pyropes (G9 and G10) based on their $\mathrm{Zr}$ contents from more enriched mantle, as seen in Figure 5

In the Kuhmo and Lentiira terrains the sampling of garnet-bearing mantle was between 800-1400 and $700-1450{ }^{\circ} \mathrm{C}$, respectively (Fig. 4a). The harzburgitic component (G10) is distributed almost throughout both mantle sections, although in Lentiira samples there is an obvious concentration near the base of the unmodified lithosphere from 1250 to $1400^{\circ} \mathrm{C}$ and an absence of G10s at temperatures $<850^{\circ} \mathrm{C}$. KaaviKuopio and Lentiira-Kuhmo share the common feature that the highest temperature at which G10 garnets exist also represents the highest temperature at which any low Zr pyropes (G9 and G10) occur (Fig. 5).

The $\mathrm{T}_{\mathrm{Ni}}$ histogram of the $\mathrm{S}$-Kuusamo garnet xenocrysts is dominated by lherzolitic grains at temperatures below $1150{ }^{\circ} \mathrm{C}$ and by high-Ti peridotitic grains at higher temperatures. The range of sampling is roughly the same as at Lentiira, with some very high temperature grains $\left(>1400{ }^{\circ} \mathrm{C}\right)$. G10 garnets are clearly concentrated around $1100{ }^{\circ} \mathrm{C}$. HighCr megacrystal grains (G1) are very rare compared to Lentiira-Kuhmo and Kaavi-Kuopio. The N-Kuusamo histogram is narrower than in S-Kuusamo and the major horizon of sampling lies between 1050 $1250^{\circ} \mathrm{C}$. This is also the horizon that contains abundant G10 and high-Cr G1 garnets, rare G9 varieties also exist at higher and lower temperatures. There are no grains with temperatures exceeding $1350^{\circ} \mathrm{C}$ in NKuusamo whereas in S-Kuusamo they are relatively 


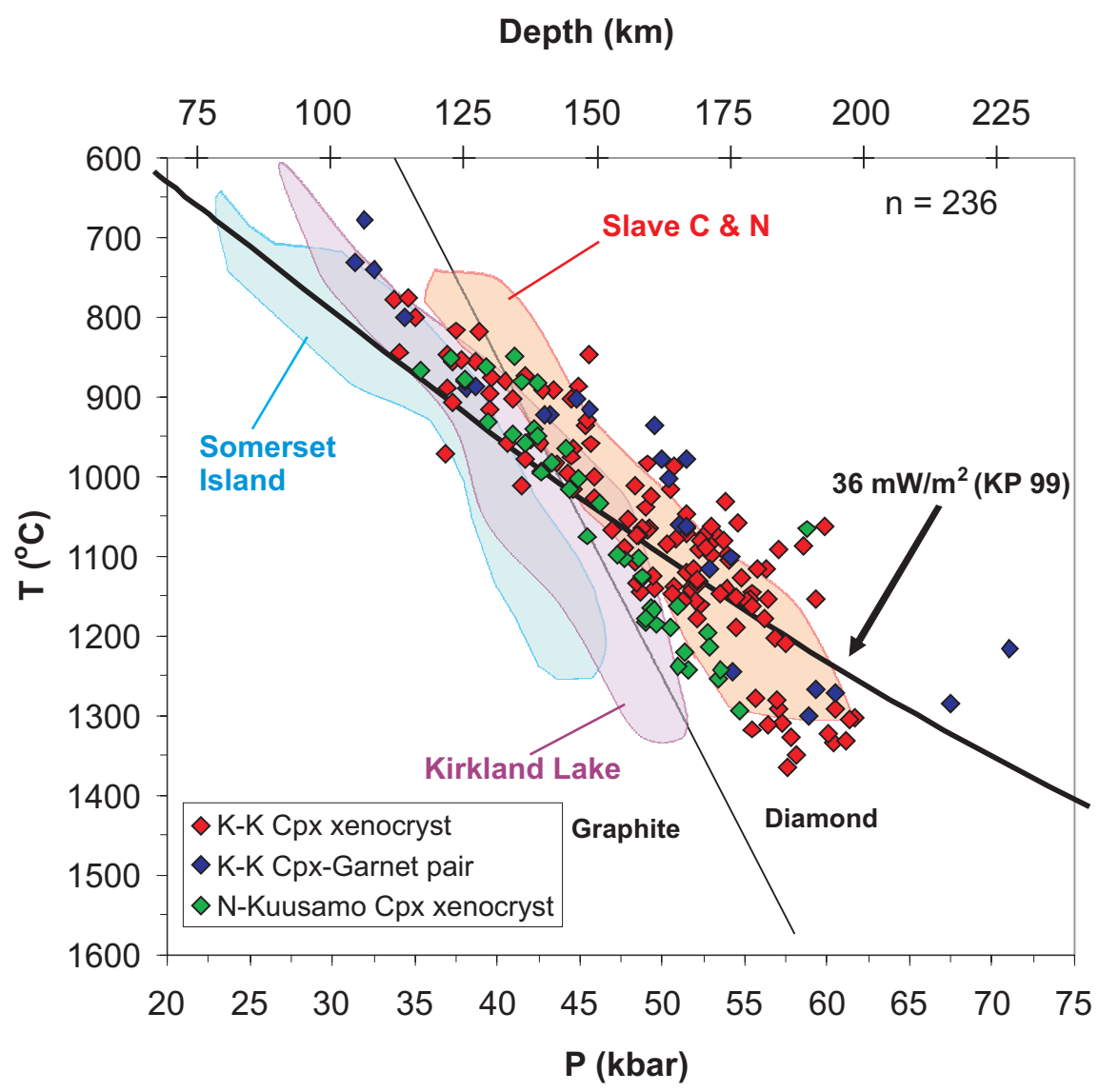

Figure 3. P-T calculated for cpx-garnet pairs from Kaavi-Kuopio and cpx xenocrysts from Kaavi-Kuopio and northern Kuusamo kimberlites using the thermobarometer by Nimis \& Taylor (2000). $36 \mathrm{~mW} / \mathrm{m}^{2}$ geotherm from Kukkonen \& Peltonen (1999) calculated for the Karelian craton at $600 \mathrm{Ma}$ and reference fields for the Slave Craton from Grütter (2009) are also marked. Depth in km is converted from pressure according to Kukkonen et al. (2003). The diamond-graphite transition is redrawn after Kennedy \& Kennedy (1976).

common, indicating that the lithosphere is thinning towards the North.

Whether $\mathrm{T}_{\mathrm{Ni}}$ above $1400{ }^{\circ} \mathrm{C}$ represent pyrope grains in lithospheric mantle equilibrated on a geotherm can be called into question. In the overall dataset, the bulk of the grains giving high temperatures are G11, high Ti pyropes, representing fertile or refertilized mantle, consistent with heating by melt percolation and implying temperatures above the conductive geotherm. This could be one explanation for the highest temperatures calculated. However, at Kuhmo, Lentiira and South Kuusamo these same high temperatures are recorded from G10 pyropes that show no evidence of melt metasomatism (see Section
4.3.3) indicating that such high temperatures can indeed exist in the lowermost sections of the non-convecting lithospheric mantle along a cool geotherm.

\subsubsection{Ti and Mg\# vs. temperature and depth}

Variations in pyrope $\mathrm{TiO}_{2}$ contents provide a useful means to map the relative fertility of the mantle sample (e.g. Griffin \& Ryan, 1995). Mg\# of garnet also reflects mantle bulk composition but is not as straightforward to interpret because it is also strongly affected by temperature dependent $\mathrm{Mg}$-Fe exchange with olivine, orthopyroxene, clinopyroxene and $\mathrm{Mg}$ chromite (Stachel et al., 2003). In addition, Ca has 

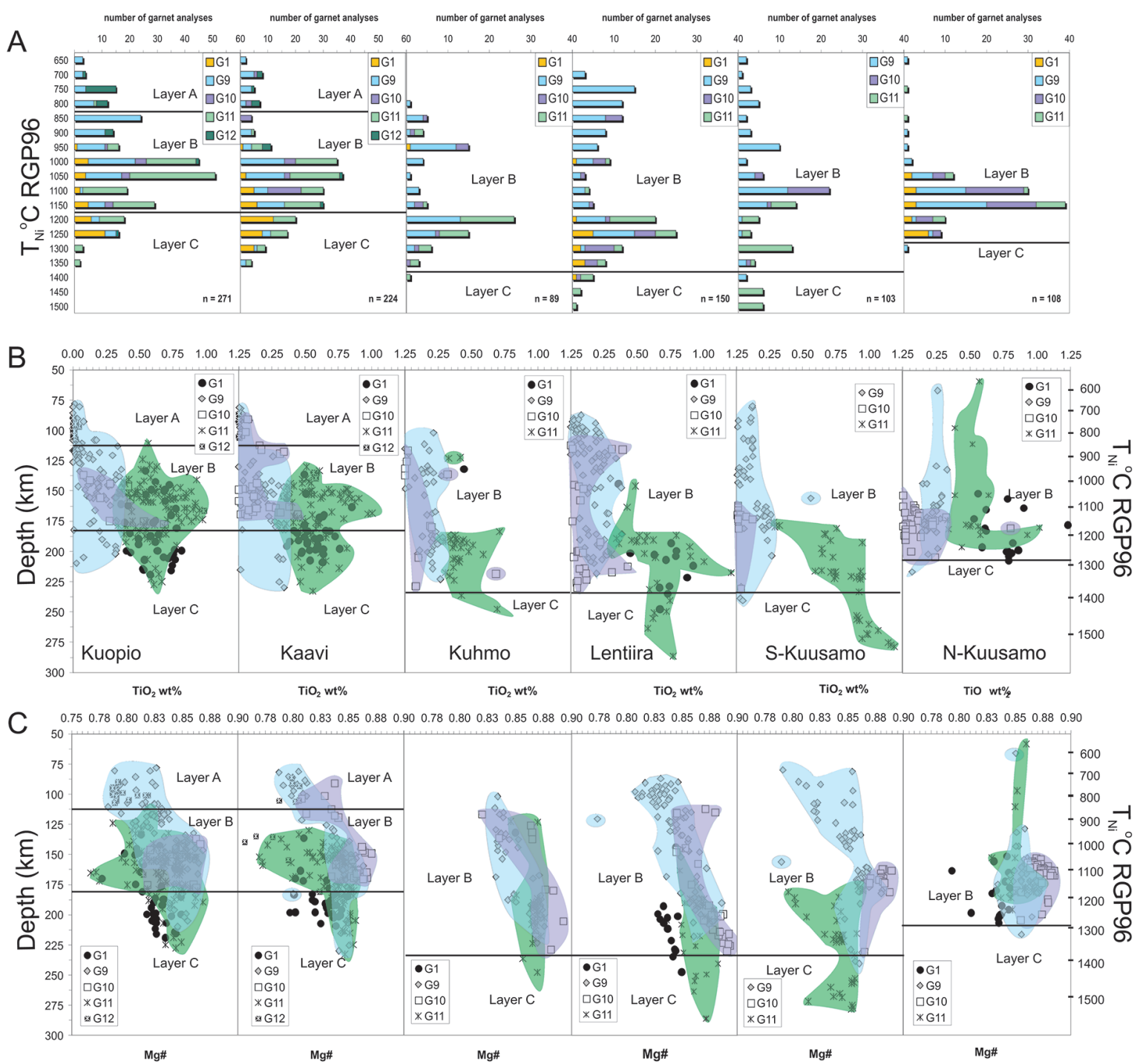

Figure 4. Distribution of $\mathrm{T}_{\mathrm{Ni}}(\mathrm{A}), \mathrm{TiO}_{2}$ vs. $\mathrm{T}_{\mathrm{Ni}}(\mathrm{B})$ and $\mathrm{Mg \#}$ vs. $\mathrm{T}_{\mathrm{Ni}}(\mathrm{C})$ for Kuopio, Kaavi, Kuhmo, Lentiira, and southern and northern Kuusamo pyrope xenocrysts. Garnet classification according to Grütter et al. (2004), $T_{\mathrm{Ni}}$ caclulated using the calibration of Ryan et al. (1996) and depths by extrapolating the $\mathrm{T}_{\mathrm{Ni}}$ temperatures of pyropes to the Kaavi-Kuopio geotherm determined by Kukkonen et al. (2003). Megacryst garnets (GI) with $\mathrm{Cr}_{2} \mathrm{O}_{3}>\mathrm{I} .5$ wt.\% and $\mathrm{MgO}>18$ wt.\% are shown for illustrative purposes, see section 4.3.I for discussion. Layers $\mathrm{A}, \mathrm{B}$ and $\mathrm{C}$ also explained in text.

a significant crystal chemical effect on the $\mathrm{Mg}-\mathrm{Fe}$ partitioning between garnet and olivine (O'Neill \& Wood, 1979; Stachel et al., 2003).

The two breaks, at 850 and $1150^{\circ} \mathrm{C}$, described previously in the Kaavi-Kuopio mantle stratigraphy, are also apparent in the $\mathrm{TiO}_{2}$ contents and $\mathrm{Mg} \#$ of garnets (Figs. $4 \mathrm{~b}$ and c). The lower temperature boundary at c. $850{ }^{\circ} \mathrm{C}$ or c. $110 \mathrm{~km}$ is marked by a break from low
Ti CCGE pyropes (G12, G9) with Mg\# around 0.80 in Layer A to pyropes that exhibit a wide range in $\mathrm{Ti}$ and $\mathrm{Mg} \#$ in Layer B. The boundary at $1150{ }^{\circ} \mathrm{C}$ or $\mathrm{c}$. $175 \mathrm{~km}$ is the limit below which only a very few $\mathrm{TiO}_{2}-$ depleted pyropes occur, G10s are absent and pyrope $\mathrm{Mg \#}$ values are less variable (Layer $\mathrm{C}$ ).

In the upper parts of these mantle sections at Lentiira and Kuhmo, $\mathrm{TiO}_{2}$ contents of pyropes vary con- 

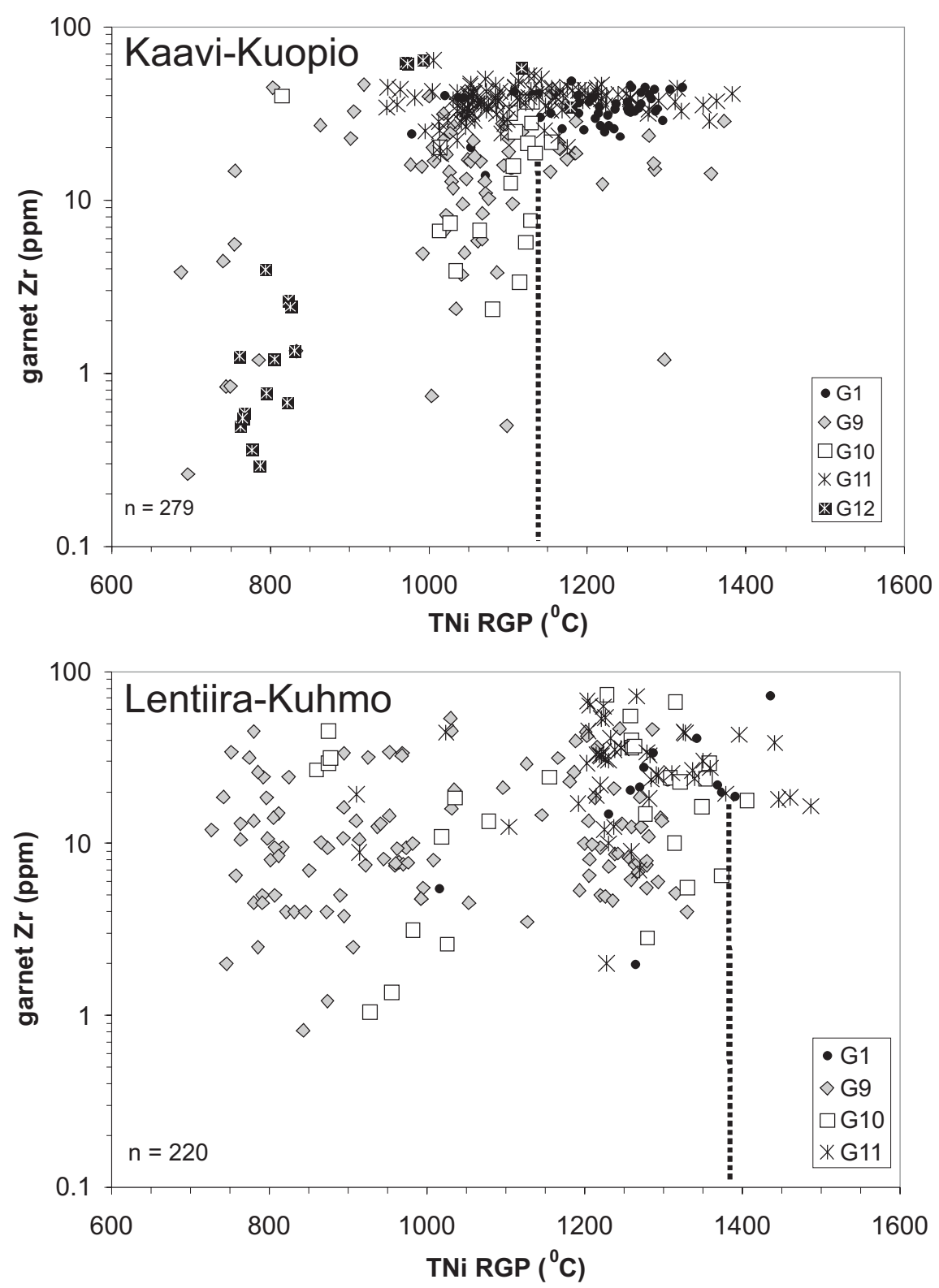

Figure 5. $\mathrm{Zr}$ contents of pyropes vs. $\mathrm{T}_{\mathrm{Ni}}$ (Ryan et al., 1996) from Kaavi-Kuopio and Lentiira-Kuhmo. Garnet classification after Grütter et al. (2004).

siderably less than those at Kaavi-Kuopio. However, there is a general increase in pyrope $\mathrm{TiO}_{2}$ with depth, especially at Lentiira (Fig. 4b). The large population of G11 high-Ti pyrope grains $\left(\mathrm{TiO}_{2} 0.5-1.0 \mathrm{wt} . \%\right)$, starting at $1150{ }^{\circ} \mathrm{C}$ or c. $175 \mathrm{~km}$ depth, represents a break in the lithosphere below which the mantle has been more affected by melt-metasomatism. Also evident in the Lentiira and Kuhmo pyrope data is a strong Mg\# versus depth correlation (Fig. 4c) that in both cases fit along well-defined linear trends evident in all of the pyrope data from these areas, irrespective of pyrope chemistry. This strong linearity suggests these portions of mantle have been have not seen any thermal perturbations close in time to kimberlite/lamproite magmatism and likely have been in equilibrium for long periods of time. 
The Kuusamo garnet data resemble those from Lentiira-Kuhmo in regard to Ti contents and Mg\#. As at Lentiira-Kuhmo, strong compositional variations in pyropes are seen only at temperatures higher than $1000^{\circ} \mathrm{C}$, corresponding to $140 \mathrm{~km}$ in depth, in both the $\mathrm{S}$ - and N-Kuusamo datasets. The $\mathrm{TiO}_{2}$ contents of garnets are relatively constant $(<0.15 \mathrm{wt} . \%)$ from 700 until $1000{ }^{\circ} \mathrm{C}$, at higher temperatures $\mathrm{Ti}$ enriched garnets appear. The most obvious difference compared to Lentiira-Kuhmo is the relatively narrow temperature range over which harzburgitic grains have been sampled, from roughly 1100 $1300{ }^{\circ} \mathrm{C}$. The thickness of the lithosphere decreases from over $250 \mathrm{~km}$ in S-Kuusamo to $220 \mathrm{~km}$ in NKuusamo.

\subsection{3 $\mathrm{Zr}$ and $\mathrm{Y}$ contents}

Systematics of the $\mathrm{Zr}-\mathrm{Y}$ concentrations in LentiiraKuhmo pyropes are compared to the field for similar data from Kaavi-Kuopio in Figure 6. The KaaviKuopio compositional field shows a roughly linear increase of $\mathrm{Zr}$ and $\mathrm{Y}$ from depleted mantle compositions (Griffin \& Ryan, 1995) of harzburgites ( $\mathrm{Zr}<$ $25 \mathrm{ppm}, \mathrm{Y}<10 \mathrm{ppm}$ ), through lherzolites and finally to enriched megacryst and G11 pyrope compositions (up to $60 \mathrm{ppm} \mathrm{Zr}$ and $30 \mathrm{ppm} \mathrm{Y}$ ). The increase in $\mathrm{Zr}$ and $\mathrm{Y}$ is coupled to increasing $\mathrm{Ti}$, and this overall trend to higher $\mathrm{Ti}, \mathrm{Zr}$ and $\mathrm{Y}$ has been interpreted to indicate an increasing effect by melt metasomatism in the Kaavi-Kuopio mantle (Lehtonen, 2005a).

Two obvious differences from the case described above are shown by the Lentiira-Kuhmo data. First, the overall level of melt metasomatism is far weaker at Lentiira-Kuhmo in terms of extreme enrichments in $\mathrm{Zr}$ and $\mathrm{Y}$. Second, a completely different style of metasomatism, one of $\mathrm{Zr}$ enrichment without concomitant Y (Fig. 6) or Ti (not shown) enrichment is exhibited by a range of pyrope types from G10 to G9 to G11. This latter style of metasomatism is only poorly developed in the mantle section at $<1150^{\circ} \mathrm{C}$, but is clear in many grains at higher temperatures. The fact that it affected such a range of pyrope types without converting them all to G11 is a clear distinction from the melt metasomatism trend, and instead points to some other metasomatic agent.

\subsection{Rare-earth element contents of peridotitic garnet xenocrysts}

\subsection{Kaavi-Kuopio}

C1-chondrite normalized $\mathrm{REE}_{\mathrm{N}}$ profiles of all garnet xenocrysts classified as megacrysts and Ti-rich peridotitic pyropes (G11), along with the majority of the
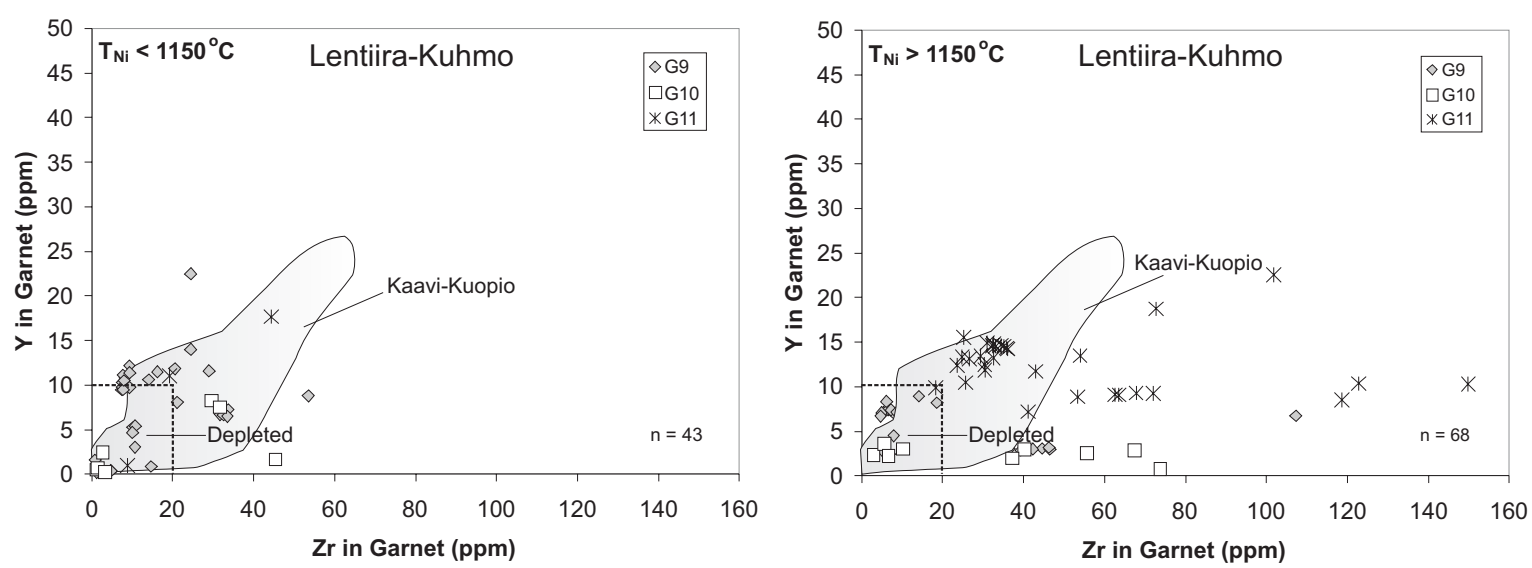

Figure 6. $\mathrm{Y}$ vs. $\mathrm{Zr}$ for the Lentiira-Kuhmo pyrope xenocrysts. The two temperature horizons (above and below $1150^{\circ} \mathrm{C}$ ) are discussed in text. Kaavi-Kuopio data from Lehtonen $(2005 \mathrm{~A})$ are shown for comparison as a shaded field. Dashed line defines depleted compositions (from Griffin and Ryan, 1995). 
lherzolitic pyropes (Layers B and C), have so called Ntype ("normal") REE profiles showing strong LREE depletion relative to MREE and HREE with steady enrichment from $\mathrm{Sm}_{\mathrm{N}}$ to $\mathrm{Yb}_{\mathrm{N}}$ (Fig. 7). This type of profile is typical of Ca-saturated mantle garnets (e.g. Shimizu, 1975). A subset of the lherzolitic and nearly all of the Layer B harzburgitic grains have sinusoidal (S-type) $\mathrm{REE}_{\mathrm{N}}$ patterns, characteristic of subcalcic harzburgitic garnets (e.g. Shimizu, 1975). The Stype $\mathrm{REE}_{\mathrm{N}}$ profiles show a weaker LREE depletion, a maximum at $\mathrm{Pr}$ or $\mathrm{Nd}$ and a trough in the MREE bottoming at Dy, Ho or Er.

Two ratios, $(\mathrm{Nd} / \mathrm{Ce})_{\mathrm{N}}$ and $(\mathrm{Nd} / \mathrm{Dy})_{\mathrm{N}}$ allow evaluation of the steepness and direction of the LREE pattern slope and the degree of sinuosity of the overall profile in garnet, respectively, and these are plotted against each other in Figure 8. A $(\mathrm{Nd} / \mathrm{Dy})_{\mathrm{N}}<1$ refers to $\mathrm{N}$-type REE patterns, and with increasing values of $(\mathrm{Nd} / \mathrm{Dy})_{\mathrm{N}}$ above 1 , the level of sinuosity in the REE profile increases. For Kaavi-Kuopio, nearly all of the $\mathrm{G} 10$ grains have $(\mathrm{Nd} / \mathrm{Dy})_{\mathrm{N}}>1$ and, importantly, all of the Ti, Y and $\mathrm{Zr}$ depleted G9 pyropes (Fig. 7) have $(\mathrm{Nd} / \mathrm{Dy})_{\mathrm{N}}>10$, showing even greater profile sinuosity than the G10 grains. Nevertheless, the bulk of the G9 grains and essentially all of the G11 and megacryst composition grains have $(\mathrm{Nd} / \mathrm{Dy})_{\mathrm{N}}<1$. The vast majority of the Kaavi-Kuopio pyropes have $(\mathrm{Nd} / \mathrm{Ce})_{\mathrm{N}}$ ranging from $2-9$ (centered around the value of 5, Fig. 8), implying a range from nearly flat to increasingly negative LREE slopes.

\subsubsection{Lentiira-Kuhmo}

As in Kaavi-Kuopio, G11 and megacrystic garnet xenocrysts are overwhelmingly $\mathrm{N}$-type based on their $\mathrm{REE}_{\mathrm{N}}$ signatures (Fig. 7). However, the G9 lherzolitic pyrope $\mathrm{REE}_{\mathrm{N}}$ profiles from Lentiira-Kuhmo contrast markedly from those at Kaavi-Kuopio. First, less than half of G9 pyropes from Lentiira-Kuhmo have $(\mathrm{Nd} / \mathrm{Dy})_{\mathrm{N}}<1$, i.e. $\mathrm{N}$-type $\mathrm{REE}_{\mathrm{N}}$ patterns. Second, the remaining G9 $\mathrm{REE}_{\mathrm{N}}$ patterns are moderately to strongly sinusoidal, similar to those in lherzolitic inclusions in diamonds reported by Stachel et al. (2004), and overlapping completely with the Len-
tiira-Kuhmo G10 grains in $(\mathrm{Nd} / \mathrm{Dy})_{\mathrm{N}}$ (Fig. 8). Third, although the data are relatively few, it appears that the Lentiira-Kuhmo G10 grain REE profiles show a systematic flattening of LREE slope with increasing sinuosity. Fourth, for the remaining grains at LentiiraKuhmo, the LREE slopes are uniformly flatter relative to Kaavi-Kuopio pyropes, with $(\mathrm{Nd} / \mathrm{Ce})_{\mathrm{N}}$ ranging from 1 to 5 for $90 \%$ of the grains. Importantly this is true even for the G11 pyrope populations, the most melt-metasomatised pyrope variety (Fig. 8).

\section{Discussion}

\section{I Thickness of lithospheric mantle}

Based on the data presented here, the lithospheric mantle thickens from about $220 \mathrm{~km}$ at Kuopio to nearly $250 \mathrm{~km}$ in the Lentiira-Kuhmo-S. Kuusamo section and then thins again to about $220 \mathrm{~km}$ at the $\mathrm{N}$. Kuusamo locality. The latter is in the direction of the Kandalaksha graben where the mantle lithosphere may have already been considerably thinned during the Middle Riphean (c. $1200 \mathrm{Ma}$ ) (Baluev et al., 2000). Of course, the source of error involved in these depth estimations are significant and include: (a) Ni measurements in pyrope at a level of only ppm, (b) uncertainties in the pyrope $\mathrm{Ni}$ thermometer calibration, (c) extrapolation to a single geotherm for all the kimberlite regions for magmatism spanning a range in age of $600 \mathrm{Ma}$, (d) deepest (highest T) pyropes not representing the true asthenosphere-lithosphere boundary due to variable sampling by the kimberlites. Despite these simplifications and difficulties, geophysical evidence such as teleseismically derived tomographic cross sections for the central Fennoscandian shield published by Sandoval et al. (2004) are surprisingly consistent with our interpretation above. This gives us confidence that the overall view of lithospheric mantle thicknesses presented in this paper is realistic and relatively accurate.

\subsection{Pyrope composition and distribution}

Not only is the lithospheric mantle thinner at the craton edges (Kuopio-Kaavi and N. Kuusamo), rel- 


\section{Kaavi-Kuopio}
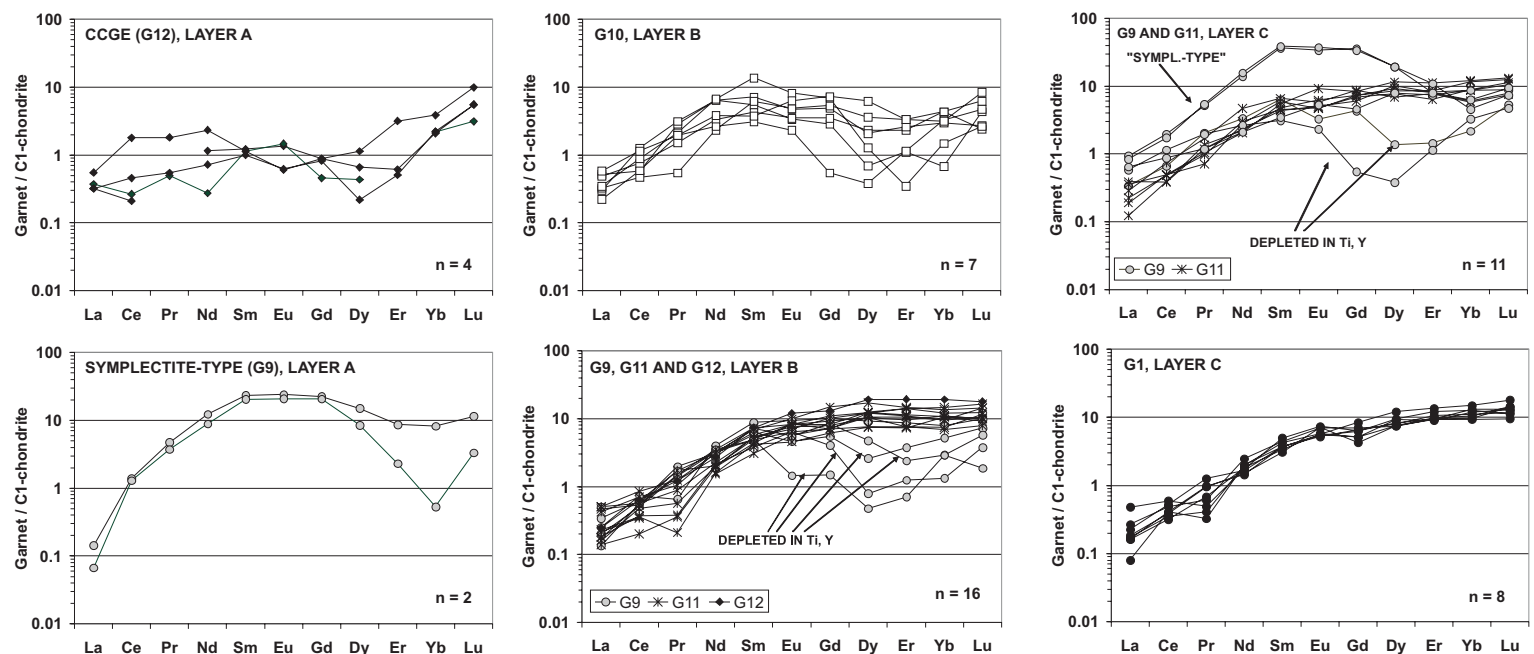

\section{Lentiira-Kuhmo}
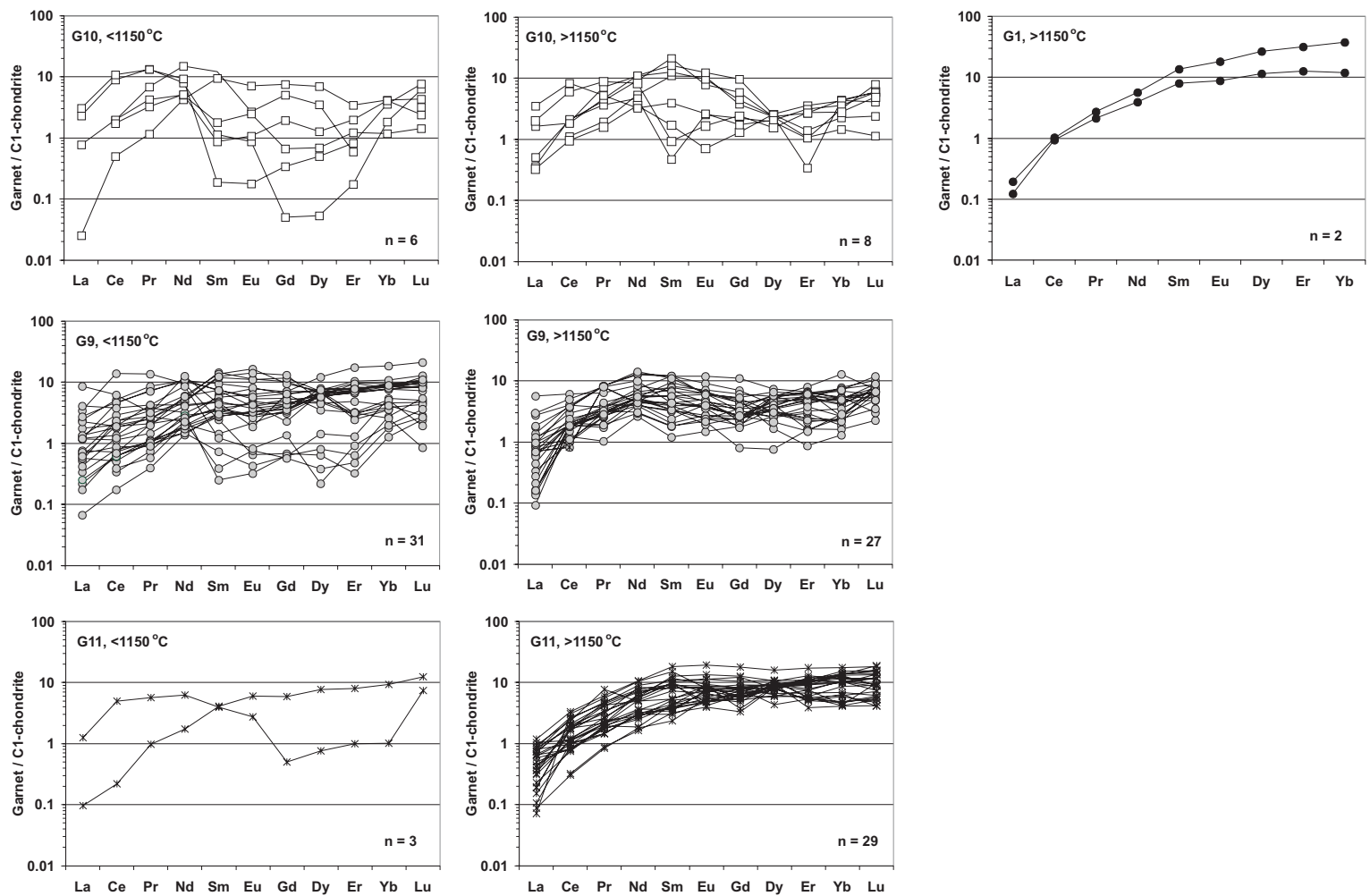

Figure 7. Cl-Chondrite normalized (McDonough \& Sun, 1995) REE profiles of mantle-derived garnet xenocrysts from Kaavi-Kuopio and Lentiira-Kuhmo kimberlites. The samples are subdivided according to rock type (Grütter et al., 2004) and temperature horizon. 

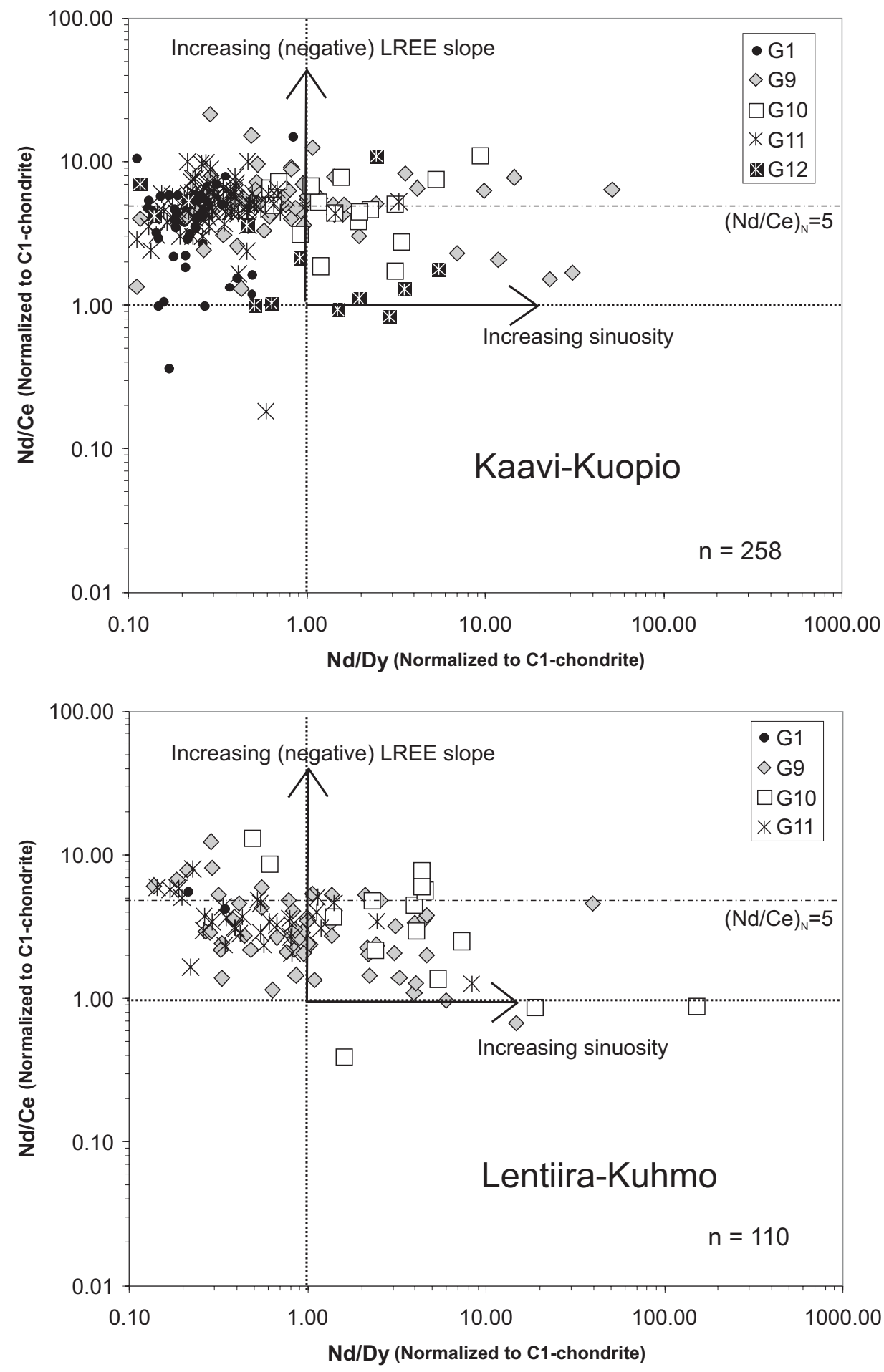

Figure 8. $\mathrm{Nd} / \mathrm{Ce}(\mathrm{N})$ vs. $\mathrm{Nd} / \mathrm{Dy}(\mathrm{N})$ for garnet xenocrysts from Kaavi-Kuopio and Lentiira-Kuhmo. $(\mathrm{N}=$ normalized to $\mathrm{Cl}$-chondrite composition after McDonough \& Sun, 1995). The diagram distinguishes between S-type (sinusoidal) and $\mathrm{N}$-type garnet $\mathrm{REE}_{\mathrm{N}}$ patterns. The reference line at $(\mathrm{Nd} / \mathrm{Ce})_{N}=5$ helps highlight the distinction in $\mathrm{LREE}$ slope in all garnet types from Kaavi-Kuopio compared to Lentiira-Kuhmo. 


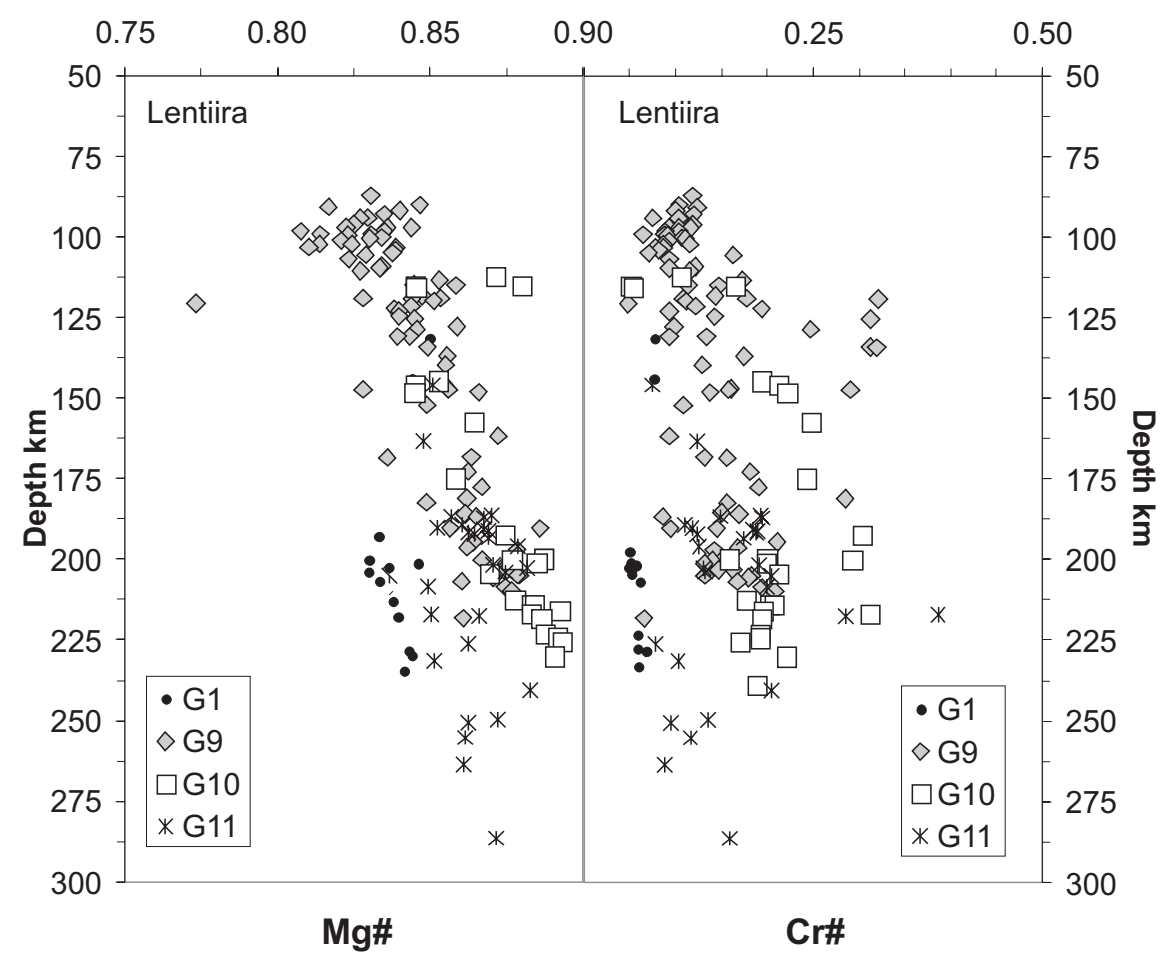

Figure 9. Distribution of Mg\# and Cr\# vs. depth for Lentiira pyrope xenocrysts. The strong linearity in the Mg\# plot is not visible in the Cr\# plot, implying that the Mg\# correlation is a function of temperature, not bulk rock composition.

ative to the core (Lentiira-Kuhmo-S. Kuusamo) but also the distribution of some of the mantle rocktypes shows similarities at the craton edges. For example G10 pyropes are limited to a 40-50 km window at the craton edges (Fig. 4), but occur throughout a thick section of up to $100 \mathrm{~km}$, in the craton core. Based on this thick section of mantle containing harzburgite, it might be expected that craton core samples would also contain a higher ratio of G10 to G9 pyropes but this is not the case for N. Kuusamo which is particularly G10-rich (Fig. 2).

Another similarity between the north and south craton edge sections is the lack of any correlation between $\mathrm{Mg \#}$ and depth, which, in contrast, is displayed nicely in the central craton sections (Fig. 4c). The overall magnesium number $(\mathrm{Mg} \#)$ of the central craton mantle lithosphere is high relative to the mantle at Kaavi-Kuopio, and seems to increase uniformly with depth. Two possibilities exist for this correlation; either it is strictly due to temperature effects on the

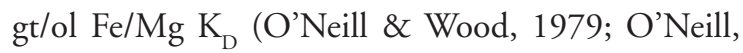
1980) or an effect of an increase in the degree of partial melting with increasing depth. To test these two alternatives, $\mathrm{Mg} \#$ and $\mathrm{Cr} \#$ versus depth for Lentiira are plotted in Figure 9. Although Mg\# increases uniformly with temperature, Cr\# does not, corroborat-

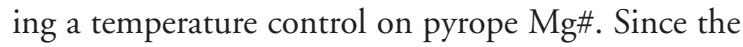
$\mathrm{Ni}$ thermometry methodology of Ryan et al. (1996) employed here is calibrated against the gt/ol Fe/Mg $\mathrm{K}_{\mathrm{D}}$ mentioned above, the strong correlation of $\mathrm{Mg} \#$ with $\mathrm{T}_{\mathrm{Ni}}$ is expected in a well-behaved, closed system. The strong correlation in the craton core data contrast with those at the craton mantle edges where there have been considerably more disturbances due to open system behavior and an influx of higher volumes of metasomatic components. 


\subsection{Metasomatic effects - Melt infiltration}

Several lines of evidence suggest that the lithospheric mantle at the craton edge has undergone considerably more melt metasomatism that the craton core mantle.

\subsection{Contrasting Mg\# \& Ti profiles}

As described above, a range in $\mathrm{Mg} \#$ of pyropes taken from a mantle section is expected, but a wide range in $\mathrm{Mg \#}$ at a specific depth requires that the pyropes sampled from that depth are derived from peridotites with a range in fertility, i.e. a range in the amount of basalt component that remains to be extracted or that has been added (e.g. Griffin et al., 2009). Returning to Figure 4c, the garnets from Kuhmo and Lentiira show significantly less variation in $\mathrm{Mg} \#$ than those from the craton edges at any given depth. This holds true even for the megacryst suite (G1) pyropes. Although enigmatic, the origin of the low $\mathrm{Cr}$ megacryst suite is normally considered as one of crystallization from asthenosphere derived melts that have undergone significant interaction with the overlying lithospheric mantle (e.g. Hops et al., 1992). We suggest that the small spread in craton-core megacryst $\mathrm{Mg \#}$ reflects a system buffered by a dominant peridotite endmember. In contrast, in the craton edge systems, melt was locally the dominant component, and produced a population of megacrysts with a broad range of $\mathrm{Mg}$ \#, from 85 (peridotite dominated) to 78 (melt dominated).

The Ti contents of pyropes at Kuhmo and Lentiira show a different relationship compared with that of $\mathrm{Mg \#} \mathrm{(Fig.} 4 \mathrm{~b}$ and $4 \mathrm{c}$ ). This is probably because of the dominance of the melt component in a melt + peridotite mixture in terms of Ti mass-balance [hundreds of ppm Ti in Karelian craton peridotites (Peltonen et al., 1999) versus 1-3 wt.\% $\mathrm{TiO}_{2}$ in Finnish kimberlites (O’Brien \& Tyni, 1999)]. Consequently even very small amounts of melt infiltration will have a large effect on pyrope Ti contents (see Burgess \& Harte, 1999). In Figure $4 \mathrm{~b}$ even the craton core pyropes show a range of $\mathrm{TiO}_{2}$ at any given depth, al- though the effect is mostly limited to the base of the SCLM where lherzolitic pyropes (G9) has been converted to high Ti peridotitic G11 pyropes. In fact the G11 pyropes from all of the mantle sections closely resemble megacryst pyropes in terms of Ti concentration (Fig. 4b), strongly suggesting that the G11 grains all represent peridotitic pyropes that recystallized due to interaction with infiltrating megacryst-producing magmas. This is further corroborated by the fact that the G11 pyropes uniformly have $\mathrm{N}$-type REE profiles indistinguishable from those of the megacryst pyropes (Fig. 7) and are uniformly enriched in $\mathrm{Y}$ and $\mathrm{Zr}$ relative to the G9 and G10 pyropes (Figs. 5 and 6).

Although we do not have trace element data for the Kuusamo pyropes, $\mathrm{Ti}$ and $\mathrm{Mg \#}$ strongly suggest that the mantle at the Kuusamo localities is quite similar to that at Lentiira-Kuhmo, albeit with a more disrupted $\mathrm{Mg} \#$ profile, suggesting a somewhat larger component of melt metasomatism. Although the NKuusamo lithospheric mantle is shallower than at the rest of the craton core sections, it nevertheless contains the same population of high $\mathrm{Mg} \#$ and low $\mathrm{Ti}$ G10 pyropes that we infer to be Archean in age.

\subsubsection{Evidence for Remnants of Layer B in Layer C}

The base of the lithosphere at Kaavi-Kuopio is sufficiently distinct from that at the core of the craton that the entire lower lithospheric mantle (Layer C) at Kaavi-Kuopio might be envisioned to have an entirely separate and unique origin. For example, given its location, it could be interpreted to represent Proterozoic mantle that was emplaced tectonically during collision of the primitive arc at $1.9 \mathrm{Ga}$ (Peltonen et al., 1999). However, there are a few lherzolitic grains from layer C, both in the Kuopio and Kaavi mantle cross-sections, which argue instead for a different paragenesis of layer $\mathrm{C}$. These rare but important grains have coupled low Ti, Y and $\mathrm{Zr}$ along with REE profiles that match very closely those of the harzburgitic grains. Moreover, these few grains mimic very closely in terms of Ti, Y, Zr and REE profiles the G9 grains that occur in the deeper levels of the craton core section at Lentiira-Kuhmo (Fig. 7). We suggest 
that these few deep G9 grains from Layer C are in fact remnants of the depleted peridotites that once existed at that depth at Kaavi-Kuopio, analogous to those from the same depth at Lentiira-Kuhmo. Melt metasomatism, as described earlier, has converted nearly all of the Layer $\mathrm{C}$ rocks to relatively fertile, but primitive mantle rock types. During this metasomatic process, all G10 and most G9 grains in layer $\mathrm{C}$ were converted to G11. It is also likely that the bulk of the peridotitic diamonds that may have existed in this lower layer were destroyed due to the oxidizing effects of the addition of melt (cf. Luth et al., 1990).

\subsection{Metasomatic effects - Fluid infiltration}

Fluid metasomatism has been invoked to explain the sinusoidal $\mathrm{REE}_{\mathrm{N}}$ patterns of harzburgitic (G10) pyropes, an observation that appears to be a worldwide phenomenon (e.g., Stachel et al., 2004), and the G10s from the Kaavi-Kuopio and Lentiira-Kuhmo mantle sections are no exceptions (Figs. 7 and 8). The worldwide link between G10 garnets and diamonds suggests that the formation of these minerals in mantle peridotite requires infiltration of $\mathrm{CHO}$-rich fluids, enriched also in incompatible trace elements (Stachel et al., 2004). Malkovets et al. (2007) has further refined this model wherein diamond is precipitated by the oxidation of asthenospheric melt-derived, methane-rich fluids that, at the same time, produce subcalcic high-Cr, S-type $\mathrm{REE}_{\mathrm{N}}$ garnet (G10) as they penetrate along fractures into pristine, highly depleted harzburgitic lithosphere. As a continuation of this process, the melts themselves invade the lithosphere, causing melt metasomatism that refertilizes harzburgite to lherzolite by introduction of $\mathrm{Ca}, \mathrm{Al}$ and $\mathrm{Fe}$, and progressively altering the $\mathrm{REE}_{\mathrm{N}}$ signatures of pyrope to N-type.

There are several observations that seem to support this model. Trace element analyses of diamonds have indeed revealed the presence of strongly light REE-enriched fluids (Rege et al., 2006) that could have caused the $S$-type $\mathrm{REE}_{\mathrm{N}}$ signatures diagnostic of G10's. Refertilization of harzburgites to lherzolites has also been evidenced by compositional zonation of garnets within mantle xenoliths (e.g. Griffin et al., 1989b, 1999; Burgess \& Harte, 1999).

The following differences in the characteristics of metasomatism seen at Lentiira-Kuhmo compared to Kuopio-Kaavi require a larger role for fluid metasomatism in the former: (a) elevated $\mathrm{Zr}$ in some grains without concomitant increases in $\mathrm{Ti}$ and $\mathrm{Y}$ or changes in major element composition (Griffin \& Ryan, 1995), (b) a larger percentage of sinusoidal $R E_{N}$ profile G9 and G10 grains, all of which are $\mathrm{Ti}, \mathrm{Y}$ and $\mathrm{Zr}$ depleted, (c) relatively minor disturbances to major element compositions (e.g., Mg\#), and (d) a broader distribution of harzburgite throughout the mantle section. Certainly the Kaavi-Kuopio and Lentiira-Kuhmo lithospheric mantle peridotites have undergone both fluid and melt metasomatism, as evidenced by the occurrence of sinusoidal G10 and highTi peridotite G11 grains at both localities, but the relative amount of fluid metasomatism is considerably less in the Kaavi-Kuopio pyrope signature. However, following the model of Malkovets et al. (2007), it is possible that this same level of fluid metasomatism previously existed in the Kaavi-Kuopio mantle section. If the fluid metasomatism-produced harzburgites provided channelways for the ingress of melts further into the lithospheric mantle, then the melts may have preferentially destroyed these harzburgite zones, erasing the record of the older fluid metasomatism event that remains prevalent in the LentiiraKuhmo mantle section.

A corollary of this model is that the distribution of diamonds and garnets in the lithosphere may be laterally heterogeneous on relatively small scales. In regard to this study, it could mean that similar compositional layers of SCLM recognized in various areas are not necessarily continuous but rather local features produced by metasomatism. However, teleseismic data, discussed briefly earlier (Sandoval et al., 2004), imply the existence of a continuous depleted thick mantle root throughout the area through which our cross section from Kuopio to N. Kuusamo is drawn. Taking all of these factors into account, Figure 10 summarizes our present understanding of the SCLM in this region. The diagram includes the 


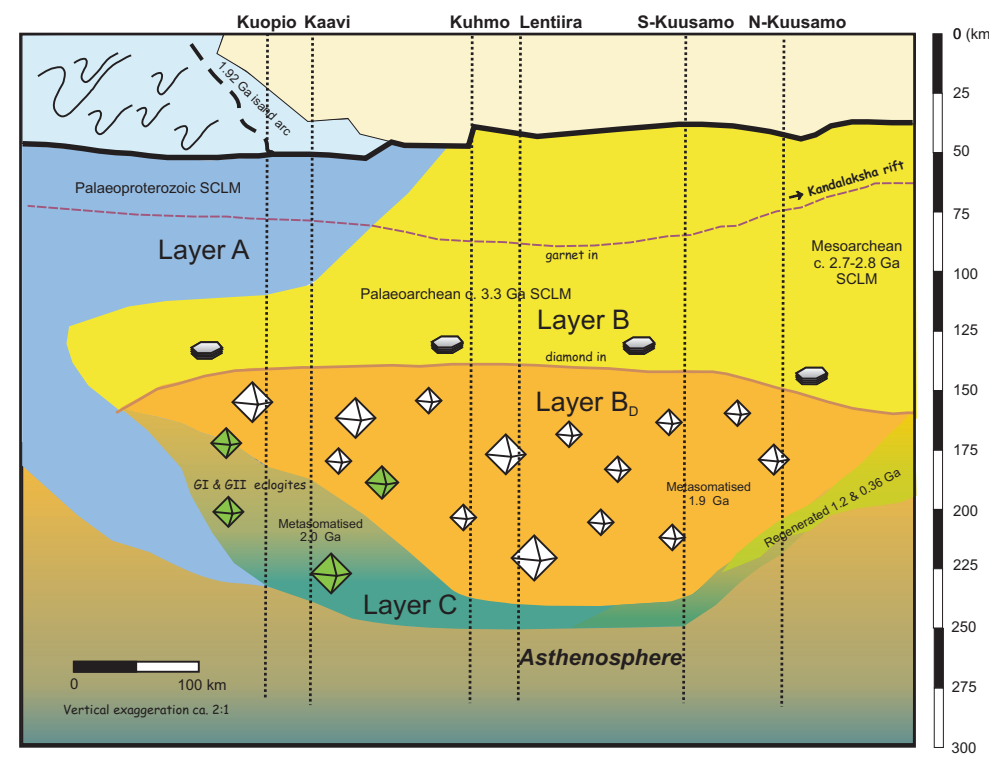

Layer A, SCLM of the Proterozoic Svecofennian orogen Layer B, Archean SCLM, graphite field Layer $\mathrm{B}_{\mathrm{D}}$, Archean SCLM, diamond field Layer C, Archean SCLM, melt metasomatised Svecofennian crust, $2.1-1.85 \mathrm{Ga}$ Archean crust, 3.5-2.6 Ga Graphite $\bigoplus$ Diamonds, peridotitic Diamonds, eclogitic

Figure 10. Simplified geological cross-section of the Archean lithosphere across the 600-km-long transect (see Fig. I for locations). The Kaavi-Kuopio SCLM stratigraphy implies a peridotitic diamond window between I40 km and I80 $\mathrm{km}$, the lower temperature stability limit of diamond (Kennedy \& Kennedy, 1976) and the deepest level where GI0 pyropes are found. A well-sampled component of highly diamondiferous eclogite xenoliths (Peltonen et al., 2002) in addition to a high number of diamond-indicative Group I eclogitic garnet xenocrysts (Lehtonen, 2005B) add significantly to the diamond potential of this mantle section in contrast to the eclogite-poor central Craton. Nevertheless, in Lentiira-Kuhmo the peridotitic diamond window determined by the diamond-graphite stability curve and the presence of GI0 garnets is extremely thick, exceeding $100 \mathrm{~km}$, starting around $140 \mathrm{~km}$ and ending near $250 \mathrm{~km}$. In Kuusamo the main diamond-bearing peridotitic horizon is between 140 and $200 \mathrm{~km}$, with possibly some diamondiferous material even at depths comparable to Lentiira-Kuhmo. Modified after Peltonen et al. (2008).

main mantle layers and connects the Archean layer B under Kaavi-Kuopio with the Archean section under Lentiira-Kuhmo-Kuusamo. In a broad sense this is correct, even though, as discussed above, in detail even the G10-bearing portions of the Archean craton mantle lithosphere have been significantly more meltmodified at the craton edges.

\section{Conclusions}

The mantle-derived xenolith and xenocryst records from Kaavi, Kuopio, Kuhmo, Lentiira and S- and NKuusamo kimberlites indicate that the subcontinental lithospheric mantle of the Karelian craton shows considerable variation from margin to core. The Karelian Craton reaches its greatest thickness in the central portion, around the Lentiira-Kuhmo-S. Kuusamo terrain $(>250 \mathrm{~km})$, and thins towards the SW and NE edges, as indicated by mantle cross-sections at Kaavi-Kuopio $(230 \mathrm{~km})$ and northern Kuusamo $(220 \mathrm{~km})$. The shallow and deep layers of the 3-layer SCLM underlying Kaavi-Kuopio have been strongly affected by the Paleoproterozoic Svecofennian orogeny as demonstrated by isotopic evidence from mantle xenoliths (Peltonen \& Brügmann, 2006), the scatter of pyrope $\mathrm{Mg \#}$ within depth profiles, the complete conversion of harzburgite-bearing mantle to lherzolite in the deepest layer (Layer C) and the overall fertility of the Archean mantle section (Layer B) that nonetheless contains remnants of extremely depleted zones. The lithospheric mantle in the LentiiraKuhmo area, in contrast, represents the most pristine, 
highly depleted, and harzburgite-rich portion of the mantle section with lherzolite and harzburgite relatively uniformly distributed throughout. The Kuusamo region is located relatively close $(300 \mathrm{~km})$ to the Belomorian graben area, which separates the Karelian and Kola cratons. Considerable melt metasomatic transformation and concomitant thermal erosion of the SCLM has taken place in the graben area, resulting in thinning of the lithosphere, an effect that can be seen in the deepest mantle layer at N.-Kuusamo. Nevertheless the Kuusamo mantle is more similar and only slightly more disrupted than the mantle at Lentiira-Kuhmo, and is significantly more pristine than the mantle at than the Kaavi-Kuopio craton edge mantle.

Pyrope trace element data consistently show stronger evidence of fluid metasomatism in the peridotites from Lentiira-Kuhmo than at Kaavi-Kuopio. This evidence includes: (a) elevated $\mathrm{Zr}$ in some grains at low Ti and Y; (b) a preponderance of G9 and G10 grains with sinusoidal REE profiles, all of which are $\mathrm{Ti}, \mathrm{Y}$ and $\mathrm{Zr}$ depleted; (c) uniformly increasing $\mathrm{Mg \#}$ with depth implying a closed, equilibrated and therefore long-lived system; (d) harzburgite sources throughout the mantle section. The evidence provided here suggests that the Lentiira-Kuhmo lithospheric mantle may represent some of the most pristine Archean mantle lithosphere anywhere on the Earth.

\section{Acknowledgements}

We would like to thank John Gurney for inviting ML to the University of Cape Town LA-ICP-MS facility and to Andreas Späth for assistance running the samples. Bo Johanson and Lassi Pakkanen provided an enormous amount of high quality electron microprobe data that were essential to this study. Ulf Andersson and Thomas Stachel provided in-depth reviews that improved the quality of this paper. Without the kind permission of the Kopane Diamond Developments, Mantle Diamonds Ltd and Sunrise Diamonds Plc to publish results from ongoing diamond exploration projects in Finland, this study would not have been possible.

\section{References}

Antonov, A. \& Ulianov, A., 2008. The lithospheric mantle beneath the Central Karelia: xenoliths from the Kostomuksha lamproites/kimberlites2. $9^{\text {th }}$ International Kimberlite Conference, Frankfurt, Germany, Extended Abstracts, No. 9IKC-A-00351.

Baluev, A.S., Moralev, V.M., Glukhovskii, M.Z., Przhijalgovskii, E.S. \& Terekhov, E.N., 2000. The tectonic evolution and magmatism of the Belomorian rift system. Geotectonics 34, 367-379.

Beard, A.D., Downes, H., 1998, Hegner, E. \& Sablukov, S.M., 2000. Geochemistry and mineralogy of kimberlites from the Arkhangelsk Region, NW Russia: evidence for transitional kimberlite magma types. Lithos 51, 47-73.

Boyd, F.R., 1989. Compositional distinction between oceanic and cratonic lithosphere. Earth and Planetary Science Letters 96, 15-26.

Burgess, S.R. \& Harte, B., 1999. Tracing lithosphere evolution through the analysis of heterogeneous G9/G10 garnet in peridotite xenoliths, I: major element chemistry. In: Gurney, J.J., Gurney, J.L., Pascoe, M.D. \& Richardson, S.H. (eds.) Proceedings of the $7^{\text {th }}$ International Kimberlite Conference, pp. 66-80.

Burgess, S.R. \& Harte, B., 2004. Tracing Lithosphere Evolution through the analysis of heterogeneous G9-G10 garnets in peridotite xenoliths, II: REE chemistry. Journal of Petrology 45, 609-633.

Grégoire, M., Bell, D.R. \& le Roex, A.P., 2003. Garnet lherzolites from the Kaapvaal Craton (South Africa): trace element evidence for a metasomatic history. Journal of Petrology 44, 629-657.

Griffin, W.L., Cousens, D.R., Ryan, C.G., Sie, S.H. \& Suter, G.F., 1989a. Ni in chrome pyrope garnets: a new geothermometer. Contributions to Mineralogy and Petrology 103, 199-202.

Griffin, W.L., Smith, D., Boyd, F.R., Cousens, D.R., Ryan, C.G., Sie, S.H. \& Suter, G.F., 1989b. Trace element zoning in garnets from sheared mantle xenoliths. Geochimica et Cosmochimica Acta 53, 561-567.

Griffin, W.L. \& Ryan C.G., 1995. Trace elements in indicator minerals: area selection and target evaluation in diamond exploration. In: Griffin, W.L. (ed.) Diamond Exploration: Into the 21st Century. Journal of Geochemical Exploration 53, 311-337.

Griffin, W.L., Shee, S.R., Ryan, C.G., Win, T.T. \& Wyatt, B.A., 1999. Harzburgite to lherzolite and back again: metasomatic processes in ultramafic xenoliths from the Wesselton kimberlite, Kimberley, South Africa. Contributions to Mineralogy and Petrology 134, 232-250.

Griffin, W.L., O’Reilly, S.Y., Afonso, J.C. \& Begg, G.C., 2009. The composition and evolution of lithospheric mantle: a re-evaluation and its tectonic implications. Journal of Petrology 50, 115-1204.

Grütter, H.S., 2009. Pyroxene xenocryst geotherms: Techniques and application. Lithos 112S, 1167-1178. 
Grütter, H.S., Gurney, J.J., Menzies, A.H. \& Wintera, F., 2004. An updated classification scheme for mantle-derived garnet, for use by diamond explorers. Lithos 77 , $841-857$.

Gurney, J.J., 1984. A correlation between garnets and diamonds. In: Glover, J.E., Harris, P.G., (eds) Kimberlite Occurrence and Origin: A Basis for Conceptual Models in Exploration. Geology Department and University Extension, University of Western Australia, Publication 8, 143-166.

Hops, J.J., Gurney, J.J. \& Harte, B., 1992. The Jagersfontein Cr-poor megacryst suite - towards a model for megacryst petrogenesis. Journal of Volcanology and Geothermal Research 50, 143-160.

Kennedy, C.S. \& Kennedy, G.C., 1976. The equilibrium boundary between graphite and diamond. Journal of Geophysical Research 81, 2467-2470.

Kopylova, M.G., Russell, J.K., Stanley, C. \& Cookenboo, H., 2000. Garnet from Cr- and Ca-saturated mantle: implications for diamond exploration. Journal of Geochemical Exploration 68, 183-199.

Kukkonen, I.T. \& Peltonen, P., 1999. Xenolith-controlled geotherm for the central Fennoscandian Shield: implications for lithosphere-astenosphere relations. Tectonophysics 304, 301-315.

Kukkonen, I.T., Kinnunen, K.A. \& Peltonen, P., 2003. Mantle xenoliths and thick lithosphere in the Fennoscandian Shield. Physics and Chemistry of the Earth 28, 349-360.

Lehtonen, M.L., 2005a. Rare-earth element characteristics of pyrope garnets from the Kaavi-Kuopio kimberlites implications for mantle metasomatism. Bulletin of the Geological Society of Finland 77, 31-47.

Lehtonen, M., 2005b. Kimberlites in Finland: information about the mantle of the Karelian Craton and implications for diamond exploration. Geological Survey of Finland, Espoo, 31 pp.

Lehtonen, M., O’Brien, H., Peltonen, P., Johanson, B. \& Pakkanen, L., 2004. Layered mantle at the Karelian Craton margin: P-T of mantle xenocrysts and xenoliths from the Kaavi-Kuopio kimberlites, Finland. Lithos 77, 593-608.

Lehtonen, M.L., Marmo, J.S., Nissinen, A.J., Johanson, B.S. \& Pakkanen, L.K., 2005. Glacial dispersal studies using indicator minerals and till geochemistry around two eastern Finland kimberlites. Journal of Geochemical Exploration $87,19-43$.

Lehtonen, M., O’Brien, Johanson, B. \& Pakkanen, L., 2008. Electron microprobe and LA-ICP-MS analyses of garnet xenocrysts from Kuhmo and Kuusamo area kimberlites. Geological Survey of Finland, Open file M41.2/2008/52.

Lobkova, L.P., Ustinov, V.N. \& Antashuk, M.G., 2006. Typomorphic features of the indicator minerals of Early Proterozoic kimberlite of Karelia. Abstracts, Conference "Diamonds and precious metals of Timan-Ural region",
Syktyvkar, Komi Republic. All-Russia Conference, November 14-17, 2006 (in Russian).

Luth, R.W., Virgo, D., Boyd, F.R. \& Wood, B.J., 1990. Ferric iron in mantle-derived garnets: Implications for thermobarometry and for the oxidation state of the mantle. Contributions to Mineralogy and Petrology 104, 56-72.

Mahotkin, I.L., Gibson, S.A., Thompson, R.N., Zhuralev, D.Z. \& Zherdev, P.U., 2000. Late Devonian diamondiferous kimberlite and alkaline picrite (Proto-kimberlite?) magmatism in the Arkhangelsk Region, NW Russia. Journal of Petrology 41, 201-227.

Malkovets., V.G., Griffin, W.L., O’Reilly, S.Y. \& Wood, B.J., 2007. Diamond, subcalcic garnet, and mantle metasomatism: kimberlite sampling patterns define the link. Geology 35, 339-342.

McDonough, W.F. \& Sun, S.S., 1995. The composition of the earth. Chemical Geology 120, 223-253.

Mutanen, T. \& Huhma, H., 2003. The 3.5 Ga Siurua trondhjemite gneiss in the Archean Pudasjärvi Granulite Belt, northern Finland. Bulletin of the Geological Society of Finland 75, 51-68.

Nimis, P. \& Taylor, W.R., 2000. Single clinopyroxene thermobarometry for garnet peridotites. Part I. Calibration and testing of a Cr-in-cpx barometer and an enstatitein-Cpx thermometer. Contributions to Mineralogy and Petrology 139, 541-554.

O’Brien, H.E. \& Tyni, M., 1999. Mineralogy and Geochemistry of Kimberlites and Related Rocks from Finland. In: Gurney, J.J., Gurney, J.L., Pascoe, M.D. \& Richardson, S.H. (eds.) Proceedings of the $7^{\text {th }}$ International Kimberlite Conference, pp. 625-636.

O’Brien, H., Lehtonen, M., Spencer, R. \& Birnie, A., 2003. Lithospheric mantle in eastern Finland: a $250 \mathrm{~km} \mathrm{3D}$ transect. In: Extended abstracts, $8^{\text {th }}$ International Kimberlite Conference, Victoria, Canada, FLA-0261, 5 p.

O'Brien, H.E., Peltonen, P. \& Vartiainen, H., 2005. Kimberlites, carbonatites and alkaline rocks. In: Lehtinen, M., Nurmi, P.A. \& Rämö, O.T. (eds.) Precambrian Geology of Finland - key to the evolution of the Fennoscandian Shield. Developments in Precambrian Geology 14, 605-644.

O’Brien, H.E., Phillips, D. \& Spencer, R., 2007. Isotopic ages of Lentiira-Kuhmo-Kostomuksha olivine lamproite-Group II kimberlites. Bulletin of the Geological Society of Finland 79, 203-215.

O’Neill, H.S.C., 1980. An experimental study of the Fe-Mg partitioning between garnet and olivine and its calibration as a geothermometer: corrections. Contributions to Mineralogy and Petrology 72, 337.

O’Neill, H.S.C. \& Wood, B.J., 1979. An experimental study of Fe-Mg partitioning between garnet and olivine and its calibration as a geothermometer. Contributions to Mineralogy and Petrology 70, 59-70.

Peltonen, P., Huhma, H., Tyni, M. \& Shimizu, N., 1999. Garnet peridotite xenoliths from kimberlites of Finland: 
nature of the continental mantle at an Archaean craton - Proterozoic mobile belt transition. In: Gurney, J.J., Gurney, J.L., Pascoe, M.D., Richardson, S.H. (eds.) Proceedings of the $7^{\text {th }}$ International Kimberlite Conference, pp. 664-675.

Peltonen, P., Kinnunen, K.A. \& Huhma, H., 2002. Petrology of two diamondiferous eclogite xenoliths from the Lahtojoki kimberlite pipe, eastern Finland. Lithos 63, 151-164.

Peltonen, P. \& Brügmann, G., 2006. Origin of layered continental mantle (Karelian craton, Finland): geochemical and Re-Os isotope constraints. Lithos 89, 405-423.

Peltonen, P., Lehtonen, M.L. \& O’Brien, H.E., 2008. Continental mantle root deep analysis: a 1000-km-long cross section of the Archean Karelian-Kola-Kuloi megacraton (Finland, NW Russia). $9^{\text {th }}$ International Kimberlite Conference, Frankfurt, Germany, Extended Abstracts, No. 9IKC-A-00089.

Rege, S., Griffin, W.L., O’Reilly, S.Y., Jackson, S.E. \& Pearson, N.J., 2006. Trace-element composition of diamond: toward a unified genetic model (abs.). 16 ${ }^{\text {th }}$ Goldschmidt Conference, 27 August - 1 September 2006, Melbourne, Australia.

Robinson, B.W. \& Graham, J., 1992. Advances in Electron Microprobe Trace Element Analysis. Journal of Computer-Assisted Microscopy 4, 263-265.

Ryan, C.G., Griffin, W.L. \& Pearson, N.J., 1996. Garnet geotherms: pressure-temperature data from $\mathrm{Cr}$-pyrope garnet xenocrysts in volcanic rocks. Journal of Geophysical Research 101, 5611-5625.
Sandoval, S., Kissling, E., Ansorge, J. \& SVEKALAPKO Seismic Tomography Working Group, 2004. High resolution body wave tomography beneath the SVEKALAPKO array - II. Anomalous upper mantle beneath the central Baltic Shield. Geophysical Journal International 157, 200-214

Schulze, D.J., 2003. A classification scheme for mantlederived garnets in kimberlite: a tool for investigating the mantle and exploring for diamonds. Lithos 71, $195-213$.

Shimizu, N., 1975. Rare earth elements in garnets and clinopyroxenes from garnet lherzolite nodules in kimberlites. Earth and Planetary Science Letters 25, 26-32.

Sobolev, N.V., Lavrentìev, Yu.G., Pokhilenko, N.P. \& Usova, N.P., 1973. Chrome-rich garnets from the kimberlites of Yakutia and their paragenesis. Contributions to Mineralogy and Petrology 40, 39-52.

Stachel, T., Viljoen, K.S., Brey, G. \& Harris, J.W., 1998. Metasomatic processes in lherzolitic and harzburgitic domains of diamondiferous lithospheric mantle: REE in garnets from xenoliths and inclusions in diamonds. Earth and Planetary Science Letters 159, 1-12.

Stachel, T., Harris, J.W., Tappert, R. \& Brey, G.P., 2003. Peridotitic diamonds from the Slave and the Kaapvaal cratons - similarities and differences based on a preliminary data set. Lithos 71, 489-503.

Stachel, T., Aulbach, S., Brey, G., Harris, J.W., Leost, I., Tappert, R. \& Viljoen, K.S., 2004. The trace element composition of silicate inclusions in diamonds: a review. Lithos 77, 1-20. 